\title{
Changes in productivity, efficiency and technology of China's crop production under rural restructuring
}

\author{
Wei Song ${ }^{\mathrm{a},{ }^{*},}$, Ze Han ${ }^{\mathrm{a}, \mathrm{b}}$, Xiangzheng Deng ${ }^{\mathrm{a}, \mathrm{c}}$ \\ ${ }^{a}$ Key Laboratory of Land Surface Pattern and Simulation, Institute of Geographic Sciences and Natural Resources Research, Chinese Academy of Sciences, \\ Beijing 100101, China \\ b Chongqing Jiaotong University, Chongqing 400074, China \\ c Center for Chinese Agricultural Policy, Chinese Academy of Sciences, Beijing 100101, China
}

\section{A R T I C L E I N F O}

\section{Article history:}

Received 16 October 2015

Received in revised form 20 July 2016

Accepted 20 July 2016

Available online 29 July 2016

\section{Keywords:}

Crop production

Total factor productivity

Three-stage Malmquist

Bootstrap-Malmquist

China

\begin{abstract}
A B S T R A C T
Food security is the fundamental problem of sustainable socioeconomic development in China. Since the 1990s, due to rapid socioeconomic development, the loss of cultivated land in China has become increasingly serious. In the context of inefficient assurances about the quantity of cultivated land, improving the productivity of crop production has become an important breakthrough in the new era to ensure food security in China. At present, China's agricultural development is at the stage of transition from traditional agriculture to modern agriculture. In the course of the agricultural transformation in China, what change has occurred to the total factor productivity (TFP) of crop production under rural restructuring becomes a problem worthy of in-depth study. Therefore, this study used the panel data of 31 provinces/autonomous regions in China from 1999 to 2008, and combined the traditional three-stage Malmquist productivity index (MPI) with the Bootstrap-Malmquist productivity index (Bootstrap-MPI) to measure the changes of the TFP of crop production in China. On the whole, the traditional MPI model underestimated the TFP of China's crop production and its components, the technical change (TC) index and technical efficiency change (TEC) index. After the ratification with the bootstrap method, the TFP of China's crop production had an annual average increase rate of 6.1\% from 1999 to 2008, with obvious fluctuations in different time periods. Since the implementation of the protective policy for grain purchase prices in the 1990s, the TFP of crop production in China began to decrease. However, the TFP increased dramatically after the rural tax reform 2002-2003.
\end{abstract}

(c) 2016 Elsevier Ltd. All rights reserved.

\section{Introduction}

As a large country in population and agriculture, crop production is the foundation of sustainable development in society and the economy in China. Since the implementation of the Reform and Opening-up Policy in 1978, China's economy has experienced a continuous rapid development (Li et al., 2014; Long, 2014a, 2014b). The food demand has thus irreversibly increased due to the growing economy and population. It is estimated that in 2030, the population of China will peak at 1.6 billion and the total demand for grain will be approximately 640 million tons (SCIC, 1996). To fill the gap between supply and demand, China's grain output needs to increase by more than 100 million tons in the next $10-20$ years.

\footnotetext{
* Corresponding author.

E-mail address: songw@igsnrr.ac.cn (W. Song).
}

However, this task is challenged by the problems that have emerged the background of rural restructuring in China.

Rural restructuring, which has been identified in Western Europe, North America and Israel in the Middle East, are taking place in the rural areas of China (Long et al., 2011a; 2011b). Spatial restructuring, industrial reshaping and administrative reorganization are the three main features of rural restructuring in China which have profound impacts on crop production (Long et al., 2016; Song and Liu, 2016). The problems emerged in rural restructuring such as nonagriculturalization, non-grain preference and abandonment of farmland use, inevitably decrease the grain production capacity in China (Liu et al., 2013; Long et al., 2012; van der Ploeg et al., 2014; Zhang et al., 2014). The contradiction among the food, farmland and population in China seems to have intensified under rural restructuring (Deng et al., 2015; Li et al., 2015a, 2015b; Song et al., 2009; Wu and Tan, 2007). Given that China cannot increase grain output by expanding cultivated land areas (Li et al., 
2015b; Song and Pijanowski, 2014), it is necessary to improve the productivity of crop production in the existing cultivated land.

After the 1990s, China implemented a series of policies, such as protective grain procurement prices and agricultural tax relief. Along with the implementation of these policies, China's agricultural development has entered a new stage: it is at the stage of transition from traditional agriculture to modern agriculture. It seems that the development of modern agriculture in China has effectively offset the negative effects of rural restructuring on grain production by changing crop productivity. For example, China's total annual grain output witnessed a consecutive increase from 2003 to 2014 under the background of nonagriculturalization, nongrain preference and abandonment of farmland use. What change has occurred in the total factor productivity (TFP) of China's crop production? What contributes to the continuous increase in grain yield? What influence do the external environment variables have?

To answer these questions, this study adopted the combined method of the three-stage Malmquist productivity index (MPI) and the Bootstrap-MPI to estimate the agricultural TFP, and correct the influence of the uncontrollable external environmental factors, such as the environmental factors affecting production activities, on the changes in China's crop production. On this basis, this article revealed the change in the TFP of China's crop production and its influencing factors against the background of agricultural reform and a mode of accelerated transformation development.

\section{Literature review}

\subsection{Development of TFP and its application in agriculture}

Total factor productivity is often interpreted as the "surplus" in total output that cannot be explained by the factor input. Early TFP estimations mainly used traditional econometric models, such as the Cobb-Douglas production function, the Solow model, the Tornqvist index, the growth accounting method, and the average function method (Carter et al., 1999; Fan and Zhang, 2002; Lin, 1992; McMillan et al., 1989; Wen, 1993). Since the 1990s, frontier analysis has gradually been introduced into the calculation of TFP, with technical efficiency taken into consideration. Based on whether a specific production function is assumed, the frontier analysis is divided into parametric methods (e.g., deterministic frontier analysis [DFA], stochastic frontier analysis [SFA]) (Aigner et al., 1976, 1977; Battese and Coelli, 1992; Headey et al., 2010) and non-parametric methods (e.g., data envelopment analysis [DEA], MPI) (Alene, 2010; Charnes et al., 1978; Coelli et al., 2005; Esposti, 2011; Headey et al., 2010). Compared with the parametric method, the non-parametric method has the advantages of simultaneously studying the multi-input and multi-output TFP issues, of having no need for a specific production function, and not being affected by subjective factors, so most scholars tend to use non-parametric frontier analysis. However, the measurement of actual technical efficiency is influenced by management efficiency, the external environment of production activities, the manager's luck and other uncontrollable variables. Therefore, some methods have been proposed, such as the one-stage model (Banker and Morey, 1986), the two-stage model (Bhattacharyya et al., 1997; Fried et al., 1993; Timmer, 1971), the three-stage model (Fried et al., 2002), and the four-stage model (Fried et al., 1999). These models effectively eliminate the interference of environmental factors and manager's luck on the measurement of technical efficiency but cannot correct the estimation error caused by a limited sample size. Therefore, some scholars (Simar, 1992; Simar and Wilson, 1998, 1999; 2007) proposed the bootstrap method to correct such estimation errors and applied this method in the correction of TFP estimations (Grosskopf, 1996; Odeck, 2009;
Tortosa-Ausina et al., 2008; Zhang and Bartels, 1998).

Since the 1970s, TFP has gradually been applied to the research on estimation and evaluation of agricultural productivity. The researches on TFP mainly include the estimation of agricultural TFP, evaluation and analysis of regional TFP differences, and analysis of the growth factor of TFP. Hayami (1969) analyzed the output elasticity of different input factors and the resultant international differences in agricultural productivity using transnational data (38 countries, including the United States, India and Japan) from 1957 to 1962. Coelli and Rao (2005) adopted the MPI to estimate the agricultural TFP of 93 countries from 1980 to 2000. The average annual TFP of China's agriculture was found to reach $6.0 \%$, which was far higher than the average growth rate of TFP $(2.1 \%)$ in other countries.

Since 1978, the TFP of agriculture in China has experienced significant changes. Fan (1997) estimated the TFP of agriculture of China using a Tornqvist-Thile index. It was found that the productivity increased by $1.51 \%$ annually from 1952 to 1995 . Nin-Pratt et al. (2010) reported that TFP growth in China was high, with an average annual growth rate of $2.11 \%$ from 1961 to 2006 . Nevertheless, the growth rate increased to $3.40 \%$ after the reforms of the late 1970s and early 1980s. Hong et al. (2010) found that China's agricultural TFP developed by $3 \%$ per year from 1978 to 2008 using the DEA method, and technical change was the main source of China's agricultural TFP growth. Many researchers reported that the planned economy, economic environment, and R\&D (research and development) could affect agricultural activities. However, when these uncontrollable factors, such as off-farm employment, farmers' incomes and natural disasters, were added into the assessment of TFP, it was not possible to present an accurate picture of productivity. When aiming to obtain an accurate estimate of TFP, it is necessary to find a method to "filter" the external environment and random factors.

\subsection{The evolution of agricultural policy in China since 1978}

Since 1978, China has gradually deregulated the prices and allowed prices to reflect basic market conditions (Nin-Pratt et al., 2010). The double-track price system was a transitional policy from a planned economy to a market economy from the mid-1980s to the mid-1990s. The transitional policy generated obvious effects on the crop production decisions of households. However, such an intervention policy could enlarge market price fluctuations (Aigner et al., 1977; Li and Zhang, 2012). In this context, the State Council of China introduced the protection price system for grain purchase in 1993. With this, the basic system of grain circulation was formed. During this period, the household responsibility system (HRS) - a basic economics system - evolved from the people's commune. The HRS equally allocated collectively owned (or village-controlled) land to individual households in each village (Deng et al., 2010; Song and Liu, 2014). As the most important land system innovation, HRS had become the primary motivator for increasing agricultural productivity in the early reform period (Huang et al., 2012).

In the second stage (from the mid-1990s to 2002), aiming to stabilize market grain prices at a reasonable level and reduce the financial burden of the grain support program (Brummer et al., 2006), the Chinese government gradually implemented policies to protect market grain prices. However, the price of agricultural products was still restricted by policies, hindering the farmers' enthusiasm for agricultural investment and application of new technology (Ren et al., 2009). During this period, the pace of agricultural economics development slowed, and grain production decreased from 508 million tons in 1999 to 431 million tons in 2003 (NBSC, 2000a; 2004a). Furthermore, in 1998, China started the second round of rural land contracts. In 1999, the policy stating that 
the duration of land contracting and management is 30 years became law. Farmers' land-use rights were strengthened to offset the adverse effects of local government's unfavorable behavior relating to crop production.

In 2000 , many grain varieties were gradually withdrawn from the protection price system. In 2003, the policy relating to a state monopoly on the purchase and marketing of grain was canceled. The land contract system entered a new stage with standardized features. The average farm size increased slightly after 2000 due to land transfers (Deng et al., 2010; Huang et al., 2012). The intensive large-scale management has been strengthened in farmland, but the fragmentation of farmland management has not been changed fundamentally (Long and Woods, 2011b). In addition, Chinese central government implemented a series of preferential agricultural policies, such as the abolition of agricultural tax, the policy of higher price for higher quality produce and subsidies for superior crop varieties, to boost agriculture development. These measures effectively reduced the burden on farmers, and increased their enthusiasm for grain production. Grain production in China thus experienced a consecutive increase for five years in succession after 2003 (NBSC, 2004a; 2005a; 2006a, 2007a; 2008a).

\section{Research methods}

\subsection{Three-stage MPI model}

\subsubsection{Stage one: traditional MPI}

The definition of the traditional MPI method is based on the distance function (Färe et al., 1992). Two periods, $t$ and $t+1$, and their corresponding input-output vectors $\left(x^{t}, y^{t}\right)$ and $\left(x^{t+1}, y^{t+1}\right)$ were assumed; $\varphi^{t}$ is a set describing the possibilities of $y^{t}$ being produced by $x^{t}$ in time period $t$, and referred to as the production possibility set. This was defined as:

$\varphi^{t}=\left\{\left(x^{t}, y^{t}\right)\right\}$

According to Shephard's (1970) research results, the distance function in time period $t$ can be defined as:

$D_{i}^{t}\left(x^{t}, y^{t}\right)=\max \left\{\theta \mid\left(x^{t} / \theta, y^{t}\right) \in \varphi^{t}\right\}$

where $i$ indicates that the distance function is to maximize $\theta$ based on the input, i.e., to minimize $x / \theta$. The distance function measures the minimum input under a given output. When $D_{i}^{t}\left(x^{t}, y^{t}\right) \leq 1$, it is equivalent to $\left(x^{t}, y^{t}\right) \in \varphi^{t}$; when and only when $D_{i}^{t}\left(x^{t}, y^{t}\right)=1$, the input-output vector $\left(x^{t}, y^{t}\right)$ is at the frontier of the production possibility $\operatorname{set} \varphi^{t}$, i.e., $\theta$ denotes the technical efficiency index.

The MPI is defined at the frontier technology of the production possibility set constituting constant returns to scale (CRS) (Fried et al., 2002). The benchmark technology in the time periods $t$ and $t+1$ is taken as the reference, and the maximum proportional changes of the corresponding $\left(x^{t}, y^{t}\right)$ and $\left(x^{t+1}, y^{t+1}\right)$ are as follows:

$D_{i}^{t}\left(x^{t}, y^{t}\right)=\max \left\{\theta \mid\left(x^{t} / \theta, y^{t}\right) \in \varphi^{t}\right\}$

$D_{i}^{t}\left(x^{t+1}, y^{t+1}\right)=\max \left\{\theta \mid\left(x^{t+1} / \theta, y^{t+1}\right) \in \varphi^{t}\right\}$

Taking the benchmark technology in the time periods $t$ and $t+1$ as a reference, the input-oriented MPI can be expressed as:

$M_{i}^{t}\left(x^{t}, y^{t}, x^{t+1}, y^{t+1}\right)=\frac{D_{i}^{t}\left(x^{t+1}, y^{t+1}\right)}{D_{i}^{t}\left(x^{t}, y^{t}\right)}$

and
$M_{i}^{t+1}\left(x^{t}, y^{t}, x^{t+1}, y^{t+1}\right)=\frac{D_{i}^{t+1}\left(x^{t+1}, y^{t+1}\right)}{D_{i}^{t+1}\left(x^{t}, y^{t}\right)}$

In order to avoid the difference caused by randomness of period selection, Caves et al. (1982) used the geometric mean of formulas (5) and (6) to measure the MPI for the productivity change from the time period $t$ to $t+1$, i.e.,

$$
\begin{aligned}
M_{i}\left(x^{t}, y^{t}, x^{t+1}, y^{t+1}\right)= & \text { TC } \times \text { TEC } \\
= & {\left[\frac{D_{i}^{t}\left(x^{t}, y^{t}\right)}{D_{i}^{t+1}\left(x^{t}, y^{t}\right)} \times \frac{D_{i}^{t}\left(x^{t+1}, y^{t+1}\right)}{D_{i}^{t+1}\left(x^{t+1}, y^{t+1}\right)}\right]^{1 / 2} } \\
& \times \frac{D_{i}^{t+1}\left(x^{t+1}, y^{t+1}\right)}{D_{i}^{t}\left(x^{t}, y^{t}\right)}
\end{aligned}
$$

When the index is greater than 1 , it indicates that the TFP increases from $t$ to $t+1$, and vice versa. The technical efficiency change (TEC) index and technical change (TC) index can be obtained by decomposition. The TEC in formula (7) gives a measure of change in technology at $t$ to that at $t+1$, which signifies that the CRS frontier shifts over time. The TEC can be decomposed into two factors (Färe and Zhang, 1994): pure technical efficiency change (PTEC), and scale efficiency change (SEC):

$$
\begin{aligned}
M_{c}^{t, t+1}= & T C_{c, i} \times \operatorname{PTEC}_{v, i} \times S E C_{i} \\
= & {\left[\frac{D_{c, i}^{t}\left(x^{t}, y^{t}\right)}{D_{c, i}^{t+1}\left(x^{t}, y^{t}\right)} \times \frac{D_{c, i}^{t}\left(x^{t+1}, y^{t+1}\right)}{D_{c, i}^{t+1}\left(x^{t+1}, y^{t+1}\right)}\right]^{1 / 2} \times \frac{D_{v, i}^{t+1}\left(x^{t+1}, y^{t+1}\right)}{D_{v, i}^{t}\left(x^{t}, y^{t}\right)} } \\
& \times\left[\left(\frac{D_{c, i}^{t+1}\left(x^{t+1}, y^{t+1}\right)}{D_{v, i}^{t+1}\left(x^{t+1}, y^{t+1}\right)} / \frac{D_{c, i}^{t+1}\left(x^{t}, y^{t}\right)}{D_{v, i}^{t+1}\left(x^{t}, y^{t}\right)}\right)\right. \\
& \left.\times\left(\frac{D_{c, i}^{t}\left(x^{t+1}, y^{t+1}\right)}{D_{v, i}^{t}\left(x^{t+1}, y^{t+1}\right)} / \frac{D_{c, i}^{t}\left(x^{t}, y^{t}\right)}{D_{v, i}^{t}\left(x^{t}, y^{t}\right)}\right)\right]^{1 / 2}
\end{aligned}
$$

Note that the subscript $v$ refers to the VRS (Variable Returns to Scale) technology, while $c$ refers to the CRS technology; PTEC and SEC are measures of pure efficiency change and scale efficiency change, respectively, and $T E C_{c, i}=P T E C_{v, i} \times S E C_{i} ; S E C_{i}=T E C_{c, i} / T E C_{v, i}$. TC remains unchanged from formula (7), and gives a measure of change in technology. While TC signifies that the CRS frontier shifts over time, PTEC reflects the change in maximum output caused by the adjustment of input under VRS.

\subsubsection{Stage two: panel SFA}

At stage two, the input-oriented Banker-Charnes-Cooper (BCC) model (Banker et al., 1984) in DEA was used for regression; the panel SFA model was then used to analyze the impact of the external environment on input slack, and finally, the original input bias was adjusted. The specific procedure is as follows (Fried et al., 2002):

(1) Calculation of slack variable by traditional DEA model:

$s_{n k}^{t}=x_{n k}^{t}-x_{n}^{t} \lambda \geq 0 \quad n=1, \ldots, N ; k=1, \ldots, K ; t=1, \ldots, T$

where $\lambda$ is a $K \times$ i vector of constants which contained the efficiency score for the $x_{n}^{t}, s_{n k}^{t}$ is the stage-one slack in the usage of the $n$-th input for the $k$-th producer in $t$-th year, $x_{n}^{t}$ is the $n$-th row of $x$ in $t$-th year, and $x_{n}^{t} \lambda$ is the optimal projection of $x_{n k}^{t}$ onto the input efficient subset for output vector $y_{i}$; 
(2) Establishment of panel SFA model: Supposed $s_{n k}^{t}$ is influenced by $n$ external environment variables $Z_{m}^{t}=\left(Z_{1 k}^{t}, Z_{2 k}^{t}, \cdots, Z_{m k}^{t}\right)$; the panel SFA model was established with input slack as the explained variable, and external environment variable as the explanatory variable:

$$
\begin{aligned}
S_{n k}^{t} & =f_{n}^{t}\left(Z_{k}^{t}, \beta_{n}^{t}\right)+V_{n k}^{t}+U_{n k}^{t} \quad n=1, \ldots, N ; k=1, \ldots, K ; t \\
& =1, \ldots, T
\end{aligned}
$$

where $\beta_{n}^{t}$ is the coefficient of external environment variables in the regression formula to be estimated; $f_{n}^{t}\left(Z_{k}^{t}, \beta_{n}^{t}\right)$ represents how external environment variables influence input slack $s_{n k}^{t} ; V_{n k}^{t}+U_{n k}^{t}$ is the composite error term; $V_{n k}^{t}$ is the random interference term conforming to $\left(0, \sigma_{v n}^{2}\right) ; U_{n k}^{t}$ is the management invalidity term following the truncated normal distribution of $\left(\mu_{n}, \sigma_{u m}\right) . V_{n k}^{t}$ and $U_{n k}^{t}$ are mutually independent. When $\gamma=\sigma_{u m} /\left(\sigma_{u m}+\sigma_{v m}\right)$ is close to 1 , the management factor is dominant; when $\gamma=\sigma_{u m} /\left(\sigma_{u m}+\sigma_{v m}\right)$ is close to 0 , random interference dominates.

(3) Adjustment of input: In order to eliminate the influence of external environment factors and random factors on efficiency change, the input of $k$ decision making unit (DMU) in the $t$-th year was adjusted to the worst environment and worst luck. The adjustment formula is as follows:

$$
\begin{aligned}
\left(x_{n k}^{t}\right)^{*}= & x_{n k}^{t}+\left[\max \left(f_{n}^{t}\left(Z_{k}^{t}, \widehat{\beta}_{n}^{t}\right)\right)-f_{n}^{t}\left(Z_{k}^{t}, \widehat{\beta}_{n}^{t}\right)\right]+\left[\max \left(\widehat{V}_{n k}^{t}\right)\right. \\
& \left.-\widehat{V}_{n k}^{t}\right], n \\
= & 1, \ldots, N ; k=1, \ldots, K ; t=1, \ldots, T
\end{aligned}
$$

\subsubsection{Stage three: the MPI after adjustment}

Stage three is a repetition of stage one. Taking the initial output value in each year and the input value adjusted by panel SFA at stage two as the new output and input respectively, $\widehat{M}_{i}(t, t+1)=\widehat{M}_{i}\left(\left(x_{n k}^{t+1}\right)^{*}, y^{t+1},\left(x_{n k}^{t}\right)^{*}, y^{t}\right)$ was calculated using MPI. At this point, the influence of external environment has been eliminated from the efficiency change.

\subsection{Bootstrap-MPI method}

Although the Malmquist MPI adjusted at the first three stages has eliminated the influence of external environment factors on efficiency factor, it was measured through the estimation of limited observation samples. The potential extreme sample value will bring about a bias to the efficiency evaluation. Therefore, bootstrap method was used to correct the MPI. The basic idea of bootstrap is to sample repeatedly in the original sample set and to builds a good approximation of the true distribution, after which the estimate simulating the distribution of original estimated samples was generated. The specific calculation process is as follows (Simar and Wilson, 1998):

(1) The input value adjusted at stage two, and raw output data were used to calculate the MPI of each sample $(k=1,2, . ., K)$ at each time point $\left(t_{1}, t_{2}\right)$;

(2) The repeated sampling method with replacement was adopted to draw the initial bootstrap sample with a scale of $\left.K,\left\{\left(\left(x_{k}^{t}\right)^{*}\right)^{\prime},\left(y_{k}^{t}\right)^{\prime}\right) ; k=1, \ldots, K ; t=1, \ldots, T\right\}$. Bivariate kernel density estimation was carried out to obtain a smooth bootstrap sample (Simar and Wilson, 1999), $\left\{\left(\left(\left(x_{k}^{t}\right)^{*}\right)^{\prime \prime},\left(y_{k}^{t}\right)^{\prime \prime}\right) ; k=1, \ldots, K ; t=1, \ldots, T\right\}$.

(3) For the smooth bootstrap sample obtained at step (2), the traditional MPI method was adopted to obtain the estimated Bootstrap-MPI value of $k$ DMUs, ${\widehat{M^{\prime \prime}}}_{i}(t, t+1)={\widehat{M^{\prime \prime}}}_{i}\left(\left(x_{k}^{t+1}\right)^{*}\right)^{\prime \prime},\left(y_{k}^{t+1}\right)^{\prime \prime},\left(\left(x_{k}^{t+1}\right)^{*}\right)^{\prime \prime},\left(\left(y_{k}^{t+1}\right)^{\prime \prime}\right)$;

(4) The first and second steps were repeated $B$ times $(B=1000)$ to obtain B-estimated Malmquist values, DMU * ${ }^{\prime \prime}{ }^{\prime \prime}(t, t+1)$, for each DMU; the deviation of ${ }^{*} \widehat{M}_{i}^{\prime \prime}(t, t+1)$ was calculated (formula (12)) to get the score of the adjusted efficiency $\widetilde{M^{\prime \prime}}{ }_{i}$, as shown in formula (13).

$$
\begin{aligned}
& \widehat{\operatorname{bias}}_{i}=B^{-1} \sum_{B=1}^{B} \widehat{ }^{*} M_{i}^{t}(b)-{\widehat{M^{\prime \prime}}}_{i} \\
& {\widetilde{M^{\prime \prime}}}_{i}={\widehat{M^{\prime \prime}}}_{i}-\widehat{\operatorname{bias}}_{i}=2{\widehat{M^{\prime \prime}}}_{i}-B^{-1} \sum_{B=1}^{B} \widehat{{ }^{*} M_{i}^{t}}(b)
\end{aligned}
$$

\subsection{Construction of confidence interval}

According to the basic idea constructing the confidence intervals of the Malmquist indices (Simar and Wilson, 1999; Arjomandi et al., 2011), the distribution of $\widehat{M}^{\prime \prime}{ }_{i}-M^{\prime \prime}{ }_{i}$ is unknown but can be approximated assessed by the distribution of ${ }^{*} \widehat{M}_{i}{ }^{\prime \prime}-\widehat{M^{\prime \prime}}{ }_{i}$, where $M^{\prime \prime}{ }_{i}$ is the true unknown index, $\widehat{M}_{i}^{\prime \prime}$ is the estimate of the Malmquist index, and ${ }^{*} \widehat{M}_{i}{ }^{\prime \prime}$ is the bootstrap estimate of the index. Hence, $a_{\alpha}$ and $b_{\alpha}$ defining the $(1-\alpha)$ confidence interval:

$\operatorname{Pr}\left(b_{\alpha} \leq{\widehat{M^{\prime \prime}}}_{i}-M^{\prime \prime}{ }_{i} \leq a_{\alpha}\right)=1-\alpha$

can be approximated by estimating the values $a_{\alpha}^{*}$ and $b_{\alpha}^{*}$

$\operatorname{Pr}\left(b_{\alpha}^{*} \leq{ }^{*} \widehat{M}_{i}^{\prime \prime}-{\widehat{M^{\prime \prime}}}_{i} \leq a_{\alpha}^{*}\right)=1-\alpha$

Thus, an estimated $(1-\alpha)$ percentage confidence interval for the $i$ th Malmquist index is given by:

${\widehat{M^{\prime \prime}}}_{i}+a_{\alpha}^{*} \leq M_{i}^{\prime \prime} \leq{\widehat{M^{\prime \prime}}}_{i}+b_{\alpha}^{*}$

\section{The measurement of the TFP of crop production}

\subsection{Selection of the output and input indexes and external environment variables}

Cultivated land is mainly used to grow crops that conform to narrowly defined agriculture. Therefore, the agricultural output value among the output values of agriculture, forestry, animal husbandry, sideline productions and fisheries was selected as the output index (Table 1). In order to avoid the deviation caused by price fluctuations, this study took 1999 as the base period for the conversion of the comparable price in each year.

Production is undertaken with the help of resources which can be categorised into natural resources (land), human resources (labor) and manufactured resources (capital). Land is a vital factor of production which helps in the production of goods and services (Lei, 2003). The area of land utilized for crop production was 
Table 1

Output and input indexes and external environment variables of crop production in China.

\begin{tabular}{|c|c|c|}
\hline Category & Indexes & Connotation \\
\hline \multirow{7}{*}{$\begin{array}{l}\text { Output index } \\
\text { Input index }\end{array}$} & AOV & The agricultural output value among the output values of agriculture, forestry, animal husbandry, sideline productions and fisheries. \\
\hline & Land & Area of cultivated land. \\
\hline & ALF & $\begin{array}{l}\text { Proportion of agricultural output value to the total value of agriculture } \times \text { the number of employed in agriculture, forestry, fishing and } \\
\text { animal husbandry. }\end{array}$ \\
\hline & AMP & $\begin{array}{l}\text { The total agricultural machinery power of farming, harvesting, and transportation that are closely related to the agricultural production } \\
\text { link. }\end{array}$ \\
\hline & EIA & The area of paddy field and irrigated land with equipped irrigation engineering or equipment which can ensure the normal irrigation \\
\hline & $\mathrm{CF}$ & The application amount of nitrogen, phosphorus and compound fertilizer that are essential for crop cultivation. \\
\hline & $\mathrm{DF}$ & $\begin{array}{l}\text { The number of large livestock actually used for agricultural production. It was assessed as follows: the number of rural households } \times \text { the } \\
\text { number of draft animals owned by } 100 \text { rural households at the end of the year } \times 100 \text {. }\end{array}$ \\
\hline \multirow{4}{*}{$\begin{array}{l}\text { External environment } \\
\text { variables }\end{array}$} & UR & The ratio of urban population to total population. \\
\hline & FES & The per capita net income of rural residents. \\
\hline & HRL & $\begin{array}{l}\text { The average education year. This index was based on the level of education of China's population divided by the average number of } \\
\text { years in education: zero years for illiterate or semiliterate; six years for primary school; nine years for junior high school; } 12 \text { for senior } \\
\text { high school (including secondary specialized schools) and } 12 \text { years for university (including undergraduate and postgraduate studies). }\end{array}$ \\
\hline & ND & The disaster-affected crop area. \\
\hline
\end{tabular}

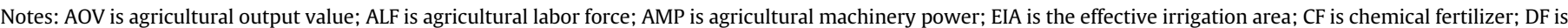
draft animal; UR is urbanization rate; FES is farmers' economic situation; HRL is human resource levels; and ND is natural disasters.

selected as an land input index i.e. cultivated land area (Table 1). Labor force is an essential productive factor for agriculture production. It provides a possibility of changing nature resources to goods. Although the labor time per unit area can accurately reflect the labor input in crop production, it cannot be directly obtained from the statistical yearbook at province level. Therefore, we select the number of employed in agriculture as a labor input according to the research of Lin (1994). Along with the progresses in agricultural technology, labor force can be replaced by agricultural machinery to some degree. However, in many underdeveloped mountain areas in China, draft animals are still the main power in crop production. Hence, agricultural machinery power and number of draft animal are also selected as another two labor inputs (Chen, 2006; Fang, 2010). Since the chemical fertilizer can improve soil fertility and increase crop yield, the amount of chemical fertilizer input is chosen as a capital input (Table 1). Water is a vital limiting factor for crop production. Agriculture water consumption is the best indicator evaluating water input in crop production. However, for the lack of this data, we selected the effective irrigation area of cultivated land as an input index.

The external environment variables are the variables that have an impact on the efficiency of crop production but are not under the subjective control of cultivators. This study takes into account four aspects, i.e., urbanization, farmers' economic situation, human resource levels, and natural disasters (Table 1). Urbanization is the process of migration and aggregation of the agricultural population to the urban area, and also the allocation of agricultural labor resources. Therefore, the urbanization rate was selected as an external environment variable. The farmers' economic situation has a direct impact on their enthusiasm for agricultural production, and further affects the efficiency of crop production. This was evaluated by the per capita net income of rural residents. Human resource level was selected as another variable because it affected the farmers' production skills and knowledge, as well as the output and efficiency of crop production. The occurrence of natural disasters in a region could reduce the crop yield. Thus it was selected as the fourth variable.

\subsection{Data sources}

This study selected the panel data of the crop production output and input and environment variables of 31 provinces/autonomous regions in China in 1999-2008 for analysis. The data were collected from the China Statistical Yearbook (NBSC, 2000b; 2001b; 2002b, 2003b; 2004b, 2005b; 2006b, 2007b; 2008b, 2009b), the China Rural Statistical Yearbook (NBSC, 2000a; 2001a; 2002a, 2003a; 2004a, 2005a; 2006a, 2007a; 2008a, 2009a), the China Agricultural Yearbook (MAC, 2000; 2001; 2002, 2003; 2004, 2005; 2006, 2007; 2008, 2009) and the China Compendium of Statistics 1949-2008 (NBSC, 2010). Table 2 describes the statistical characteristics of the panel data of China's 31 provinces/autonomous regions in 1999-2008.

In the first stage in this study, the traditional MPI of 31 provinces/autonomous regions from 1999 to 2008 was measured with DEAP 2.1 software. In the second stage, the DEA-BCC model was used to measure the input slack of crop production each year for each province. Panel SFA regression was carried out on the input slack and external environment variables using Stata software to calculate the influence of external environment variables on input slack, and the deviation of the original input was rectified. In the third stage, the original output and the rectified input were used to calculate the MPI again. Finally, the bootstrap rectification of MPI was carried out with MaxDEA software.

\section{Results}

\subsection{The first stage: the results of traditional MPI}

Calculations were carried out with a traditional MPI model (section 3.1.1.) to obtain the changes in the TFP of China's crop production (Fig. 1). On the whole, without the consideration of external environment variables and random factors, the TFP of crop production from 1999 to 2008 improved. The average annual growth of TFP reached 3.5\%, wherein the average annual growth of the TEC index was $0.3 \%$, and that of the TC index was $3.2 \%$. That is, the utilization of the input factors may have not been greatly improved, while the production frontier has experienced greater movement caused by bringing in advanced techniques. At different stages, the TFP of crop production decreased only in 1999-2000 and was always greater than 1 in other years. Crop productivity increased most from 2003 to 2004, with the growth rate reaching $10.1 \%$. After the decomposition of efficiency, it was found that the TEC index fluctuated significantly in the 10 years between 1999 and 2008. Comprehensive technical efficiency increased in 2000-2001, 2003-2004 and 2006-2008 and decreased in other time periods. Technical efficiency improved most significantly in 2007-2008, with an increased amplitude of $10.9 \%$; it decreased by $4.3 \%$ in 2002-2003. Comparatively speaking, the TC index fluctuated 
Table 2

Descriptions of data characteristics of output, input and environment variables of crop production in China during 1999-2008.

\begin{tabular}{|c|c|c|c|c|c|c|c|}
\hline Index & Unit & Sample size & Average value & Standard deviation & Median & Minimum value & Maximum value \\
\hline \multicolumn{8}{|c|}{ (1) Output index } \\
\hline $\begin{array}{l}y \\
(2) \operatorname{Inp}\end{array}$ & $\begin{array}{l}100 \text { million Yuan } \\
\text { dexes }\end{array}$ & 310 & 554.15 & \multicolumn{3}{|c|}{ (2) Input indexes } & 2394.32 \\
\hline$x_{1}$ & 10 thousand ha & 310 & 401.34 & 269.10 & 415.86 & 23.17 & 1183.84 \\
\hline$x_{2}$ & 10 thousand people & 310 & 532.18 & 431.47 & 448.45 & 20.48 & 2270.49 \\
\hline$x_{3}$ & 10 thousand kilowatts & 310 & 2060.60 & 2162.34 & 1523.85 & 95.32 & 10350.00 \\
\hline$x_{4}$ & Thousand ha & 310 & 1773.70 & 1375.00 & 1444.60 & 151.10 & 4989.20 \\
\hline$x_{5}$ & 10 thousand tons & 310 & 148.18 & 123.57 & 119.77 & 2.50 & 601.68 \\
\hline $\begin{array}{l}x_{6} \\
\text { (3) } \mathrm{Ext}\end{array}$ & $\begin{array}{l}10 \text { thousand heads } \\
\text { environment variables }\end{array}$ & 310 & 242.00 & \multicolumn{3}{|c|}{ (3) External environment variables } & 670.00 \\
\hline$z_{1}$ & $\%$ & 310 & 42.63 & 15.18 & 40.23 & 16.83 & 87.50 \\
\hline$z_{2}$ & Yuan & 310 & 3061.56 & 1495.53 & 2570.21 & 1309.46 & 9459.50 \\
\hline$z_{3}$ & Year & 310 & 7.76 & 1.22 & 8.03 & 2.28 & 10.31 \\
\hline$z_{4}$ & Thousand ha & 310 & 1498.21 & 1188.10 & 1205.15 & 0.001 & 6659.00 \\
\hline
\end{tabular}

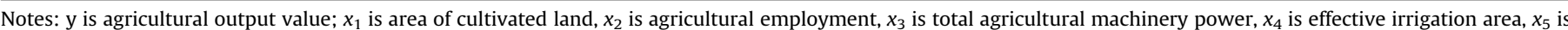

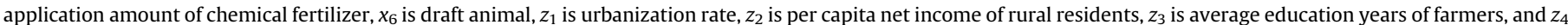
is disaster-affected crop area.

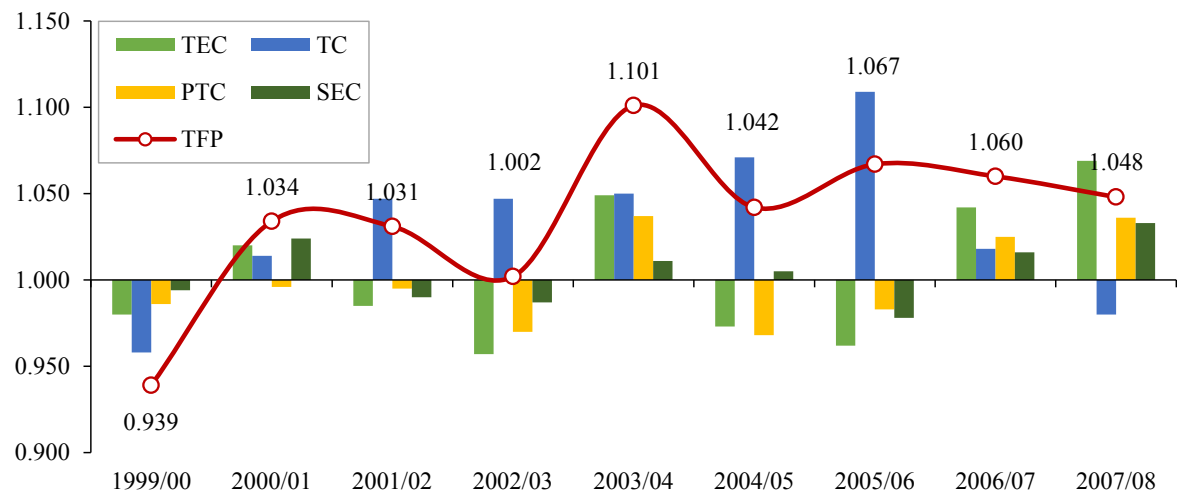

Fig. 1. Changes in MPI of China's crop production in 1999-2008 in stage-one analysis.

slightly and only fell behind in two time periods: 1999-2000, and 2007-2008. Production technology advanced in other time periods. To sum up, the analysis of traditional MPI indicates that technical progress was the leading factor for changes in the TFP of crop production.

\subsection{The second stage: panel SFA}

The input slack separated by formula (9) was taken as the explained variable, and the four external environment variables selected above were taken as the explanatory variables for panel SFA. The results are shown in Table 3. It can be seen that the coefficients of most of the external environment variables with respect to input slack variables passed the significance test, except for the application amount of chemical fertilizer. All the $\gamma$ values in the regression of the four external environment variables to six input slack variables, respectively, were close to 0 . This indicates that the random error of input slack variables dominated.

When the regression coefficient is negative, it indicates that the increase in environment variables is conducive to reducing the input slack - that is, avoiding waste and inefficient use of input variables. When the regression coefficient is positive, it indicates that the increase in external environment variables could result in an increase in input slack and hence the waste of input variables or increase in output.

Urbanization rate $\left(z_{1}\right)$ : The level of urbanization improves the different input slack variables in various ways. The coefficients of the urbanization rate, with respect to the area of cultivated land, agricultural employment, effective irrigation area, application amount of chemical fertilizer, and draft animals, were all negative, while with respect to total agricultural machinery power the coefficients were positive. All the slack variables' coefficients, except for the application amount of chemical fertilizer, passed the significance test of $1 \%$.

Per capita net income of rural residents $\left(z_{2}\right)$ : The coefficients of this variable with respect to the six input slack variables were positive. As in the previous example, only the application amount of chemical fertilizer did not pass the significance test while the coefficients of the other slack variables all passed the significant test of $1 \%$. That is to say, the increase in the per capita net income of rural residents would blindly increase the inputs of various input elements, leading to inefficient use of the cultivated land. In addition, much of the labor force returned to agricultural production attracted by the increased household income, leading to increased redundancy of the labor force (Guo et al., 2010).

Average number of education years of farmers $\left(z_{3}\right)$ : The regression coefficients of this variable to the six input slack variables were negative. All the slack variables' coefficients passed the significance test of $1 \%$, except for the application amount of chemical fertilizer. The accumulation of human capital is widely recognized as a crucial prerequisite for decreasing the cost of disseminating agriculture technology. Average education years could represent human capital investment. A well-educated farmer would arguably be more able to effectively use advanced technology, avoiding the inefficient use of input elements.

Disaster-affected crop area $\left(z_{4}\right)$ : The disaster-affected crop area 
Table 3

Results of panel SFA at the second stage.

\begin{tabular}{|c|c|c|c|c|c|c|}
\hline Regression coefficient & $x_{1}$ & $x_{2}$ & $x_{3}$ & $x_{4}$ & $x_{5}$ & $x_{6}$ \\
\hline$\overline{z_{1}}$ & $-0.706^{* * *}$ & $-1.865^{* * *}$ & $0.678^{* * *}$ & $-3.669^{* * *}$ & $-8.150 \times 10^{10}$ & $-1.693 \times 10^{5 * * *}$ \\
\hline$z_{2}$ & $0.002^{* * *}$ & $0.005^{* * *}$ & $0.015^{* * *}$ & $0.017^{* * *}$ & $2.420 \times 10^{11}$ & $6.773 \times 10^{2 * * *}$ \\
\hline$z_{3}$ & $-0.476^{* * *}$ & $-0.496^{* * *}$ & $-1.629^{* * *}$ & $-4.303^{* * *}$ & $1.850 \times 10^{9}$ & $-1.773 \times 10^{6 * * *}$ \\
\hline$z_{4}$ & $0.009^{* * *}$ & $0.004^{* * *}$ & $0.017^{* * *}$ & $0.031^{* * *}$ & $1.160 \times 10^{11}$ & $-76.045^{* * *}$ \\
\hline Log likelihood & -1434.137 & -1601.739 & -2015.556 & -1947.334 & $-1.069 \times 10^{3}$ & $-4.603 \times 10^{3}$ \\
\hline$\sigma_{u}$ & 37.572 & 64.515 & 245.136 & 196.709 & 11.583 & $1.033 \times 10^{6}$ \\
\hline$\sigma_{v}$ & $2.090 \times 10^{6}$ & $8.000 \times 10^{6}$ & $1.360 \times 10^{5}$ & $2.660 \times 10^{6}$ & $1.530 \times 10^{7}$ & 26.440 \\
\hline$\gamma$ & $0.000^{* * *}$ & $0.000^{* * *}$ & $0.000^{* * *}$ & $0.000^{* * *}$ & $0.000^{* * *}$ & $0.000^{* * *}$ \\
\hline
\end{tabular}

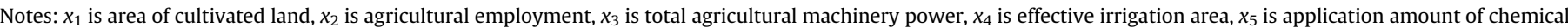

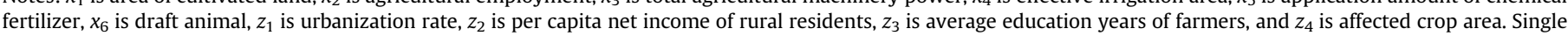
asterisk $\left({ }^{*}\right)$ denote $\mathrm{p}<10 \%$; double asterisk $\left({ }^{* *}\right)$ denote $\mathrm{p}<5 \%$; and Triple asterisks $\left({ }^{* * *}\right)$ denote $\mathrm{p}<1 \%$.

had different impacts on the six input variables. The coefficients with respect to the area of cultivated land, agricultural employment, effective irrigation area, and application amount of chemical fertilizer were positive, however, draft animal was negative. Except for the application amount of chemical fertilizer, the coefficients of all variables all passed the $1 \%$ significance test. The occurrence of natural disasters in a region could reduce the crop yield. From the aspect of production frontiers, the reductions in crop yield were caused by the input slack. That is, natural disasters will waste inputs that should be utilized to produce crops.

From the perspective of the significance test, only the application amount of chemical fertilizer had a poor estimation result. As an important variable related to crop yield, the amount of applied chemical fertilizer depends greatly on the planting structure, which has higher commercial value. Furthermore, according to previous studies, the difference in the amount of applied chemical fertilizer among different provinces is small. Except for the chemical fertilizer, the external environment variables had a significant impact on the other input slack variables (confidence level 99\%). To achieve an exact measurement of TFP, it is essential to ensure the same management environment and luck for all areas by eliminating the influence of non-operational management factors in the input slack variables of cultivated land.

\subsection{The third stage: MPI after adjustment}

Formula (11) was used to adjust the original input, and the adjusted input and original output were used as the new input and output respectively to calculate the MPI at the third stage (Fig. 2). After the elimination of the impact of external environment variables on the measurement of productivity change, the MPI of crop production decreased in 1999-2000 and 2006-2007 compared with the first stage, but improved in other time periods. The average annual increase in the productivity of crop production was 7.6\%. Specifically, the average annual change of the TEC index increased from $0.5 \%$ to $0.8 \%$ in the stage-one MPI measurement. The average annual change of the TC index increased from $3.2 \%$ at the first stage to $6.8 \%$, increasing by $3.6 \%$. So it can be seen that the measurement of the TC index is mainly limited by the external environment variables. In different time periods, following the elimination of external environment factors, the fluctuation range of the MPI of crop production increased compared with the first stage. In 1999-2000, the change in MPI of crop production increased from $-6.1 \%$ at the first stage to $8.4 \%$, increasing by $14.5 \%$; in 2000-2001, MPI decreased from $3.4 \%$ at the first stage to $-3.9 \%$, decreasing by $7.3 \%$. The change in MPI of crop production remained the same in other time periods. In the survey period, urbanization rate, per capita net income of rural residents, and average education years of farmers showed a steadily increasing trend with slight fluctuations. Due to the influence of climate, natural, and other uncertainty factors, the disaster-affected crop area was the main cause for significant fluctuations in the MPI in the third stage. Two events that probably had a significant impact on the measurement of MPI fluctuation in the third stage were the catastrophic flood disaster in 1998, and the continuous drought from 2000 through 2001.

\subsection{Bootstrap-MPI}

In order to improve the accuracy of measurement, a bootstrap method was applied (Section 3.2) to measure the change in TFP of crop production, and both the estimated value of efficiency and confidence levels were provided. The arithmetic average method was used to process the MPI and its constituent indexes (TEC and

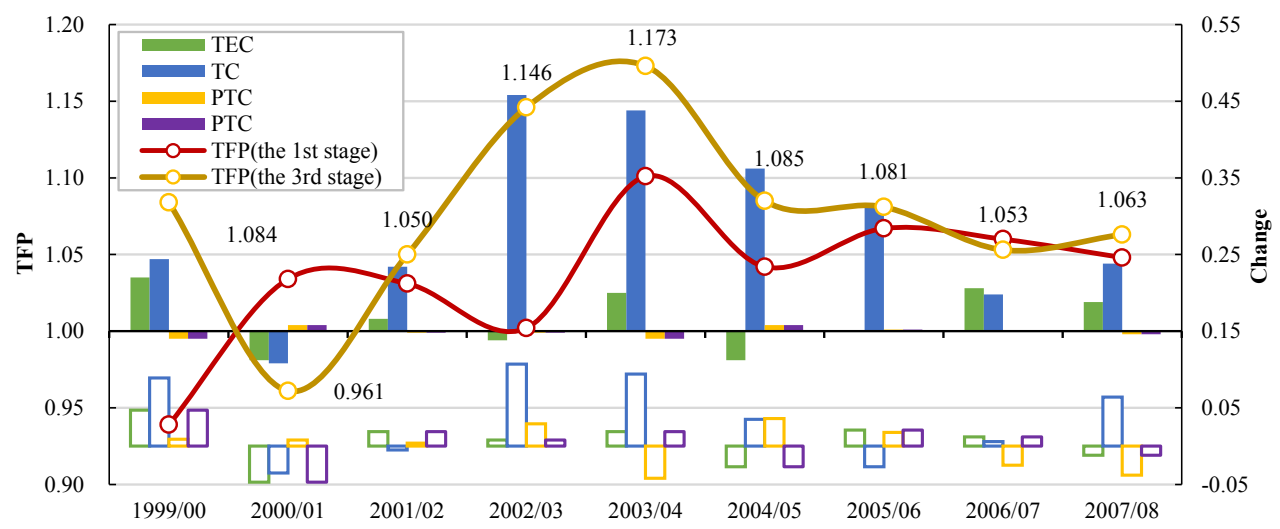

Fig. 2. Average annual MPI of crop production in 1999-2008 at the stage-three analysis. 


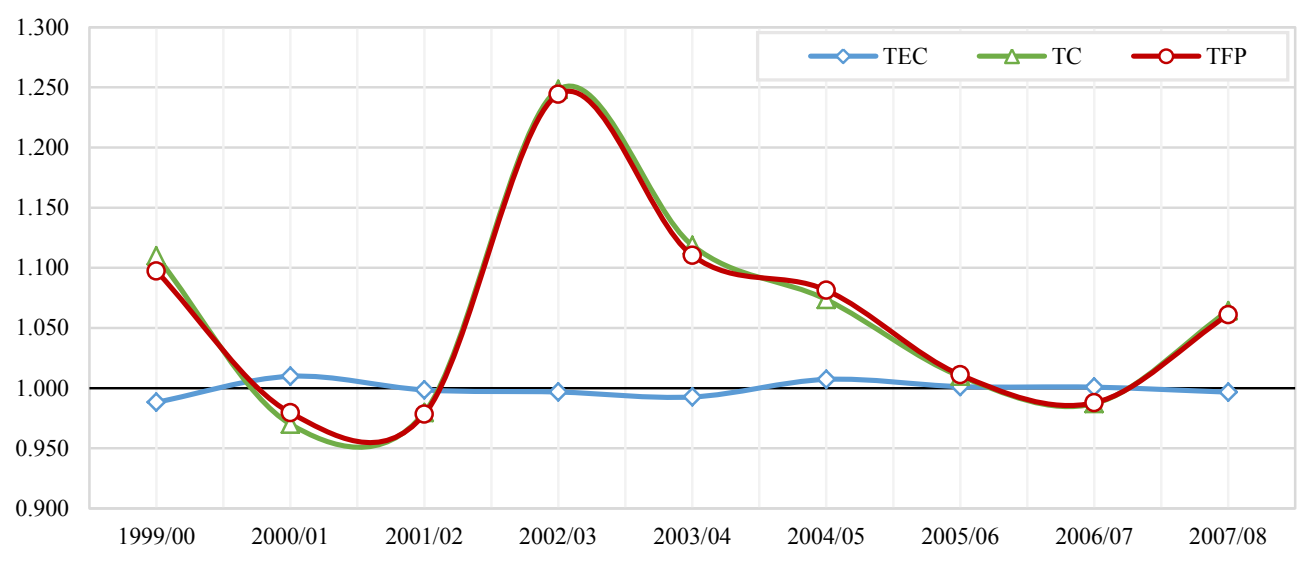

Fig. 3. Changes in Bootstrap-MPI of China's crop production and its decomposed efficiencies in 1999-2008.

TC) of crop production of 31 provinces/autonomous regions after rectification with the bootstrap method and to obtain the change in Bootstrap-MPI of China's crop production (Fig. 3).

The average annual increase in TFP of China's crop production between 1999 and 2008 was 6.1\%, and the overall productivity showed a trend of continuous improvement. But the growth was also accompanied by marked fluctuations: generally two stages were identified, i.e., a fluctuant decreasing stage (1999-2002) and a rapid increasing stage (2002-2008). In 1993, China formally established the protection system of grain purchase prices. Since 1997, China has gradually implemented policies and measures to protect market grain prices in order to maintain them at a reasonable level. However, the price of agricultural products is still restricted by policies, hindering the farmers' enthusiasm for agricultural investment and application of new technology (Ren et al., 2009). Such an impact might have caused the continuous decrease in the productivity of crop production, and have been responsible for the negative growth between 2000 and 2002. Since 2000, the Chinese government has launched many agricultural policies, e.g., the price protection of grain, the state monopoly system for the purchase and marketing of grain and a policy on agricultural taxes, which effectively reduce the burden on farmers and increase their enthusiasm for production. In this context, the TFP of crop production also increased rapidly - especially in 2002-2003 when its growth rate reached $24.44 \%$.

From the perspective of composition, the TFP of China's crop production significantly depended on technical progress, rather than an improvement in technical efficiency. The reform of the agricultural policy system played a significant role in mobilizing farmers' enthusiasm and increasing the demand for production technology. In recent years, the Chinese government has implemented a series of agricultural technology policies, covering the introduction of agricultural technology, technology transfer, and its technology promotion policy (Jin et al., 2010). The total investment in agricultural research has been increasing year by year, and the annual average growth rate was 8\% from 1999 to 2008 (NBSC, 2000a; 2009a). In that period, China's agricultural scientific research system also gradually transformed to the enterpriseoriented innovation system, and the methods for technology promotion diversified. Under the combined effects of policy stimulus, market dominance, and company and farmers' independent choice, the TC index of crop production in China improved significantly, with an annual growth rate reaching $6.2 \%$. The variation trend of the TC index was similar with that of the TFP index, which means that the TC index contributed a lot to the change in TFP of crop production.

During the research period, the productive technical efficiency of China's crop production showed a slight negative growth with an annual average growth rate of $-0.1 \%$. The TC index fluctuated slightly with a fluctuation range between $-1.2 \%-1.0 \%$. Two subperiods were identified: 1999-2004 and 2004-2008. Before 2004, the TEC index showed a declining trend that had a negative impact on the growth of TFP of crop production; it showed a steady and slightly increasing trend between 2004 and 2008, but had little effect on improving TFP.

\section{Discussion}

\subsection{Urbanization could increase the efficiency of the crop production}

Urbanization impacts on the efficiency of the crop production in two aspects: scale operation of farmland, and the use of advanced technology. In the process of urbanization, the increasing off-farm employment and cultivated land rental transactions promote the large-scale operation of farmland (Cao and Birchenall, 2013; Huang et al., 2012). In addition, urban development affects the promotion of advanced technologies. On the one hand, many advanced agricultural technologies need the support of an industrial sector. On the other hand, urban development has spillover effects on advanced agricultural technology. The spillover effects could promote the transfer and spread of advanced agricultural technology thus increasing output and reducing input slack.

\subsection{The use of advanced technology is inadequate and have region differences}

According to the characteristics of agricultural production, the effectiveness of technical efficiency is influenced by the application of production technology adopted by farmers, allocation of input resources and the management level of production. Furthermore, it is influenced by the production frontier. When advanced technology is applied by only a few producers, the production frontier will shift substantially because only minor units have improved the production efficiency due to adopting advanced techniques, while most units decrease in efficiency due to their failure to use advanced techniques. Thus, the overall technical efficiency would be low.

If the technology adopted by producers is popular and has been utilized for a long time, the technical efficiency remains at a high level. Overall, it was difficult for the TEC and TC indexes to grow synchronously between 1999 and 2008: technical progress and the loss of technical efficiency coexisted in crop production. After eliminating the external environment variables that influence 
productive technical efficiency, such as natural disaster and farmers' education years, the changes in the technical efficiency of crop production illustrated that the promotion of advanced technology in crop production is inadequate and there were also regional differences in the application of technology.

\subsection{Implications of crop production from the perspective of TFP}

Many researchers have measured the TFP in agriculture or its sub-sectors. However, it is difficult to assess the accurate change value of TFP in agriculture. In a frontier analysis, the results are easily affected by the data source and study period. Most findings reported that the TFP of agriculture (including crop production) in China varied from 2\% to 5\% from 1998 to 2008, which is consistent with the result from our first stage regression. When we split the influence of environment variables and management noise in the third stage, the fluctuation in the growth of MPI is larger than that of other researches.

The health of the agricultural economy in China will increasingly rely on the growth of TFP, instead of the growth of inputs. According to our findings, the growth of TFP in crop production had certain distinguishing characteristics, e.g., it was susceptible to agricultural policy, technical progress coexisted with the loss of technical efficiency, it strongly relied on technical progress, and advanced technologies were inadequately disseminated. To make full use of the input elements, crop production should pay attention to the popularization and innovation of advanced technology. However, although stripping off the external environment factors and random factors can clearly depict the changing trends and characteristics of productivity, it is difficult to remove the influence of these variables in practice. Hence, to improve efficiency of crop production, some measures are needed, e.g., promoting the standardization of land transfer, operating the farmland to a proper scale, strengthening construction of the rural infrastructure and increasing investment in human capital and so forth.

\subsection{Limitations of the research}

According to the decomposition method proposed by Fare et al. (1994), the enhanced decomposition to decompose MPI needs the same repeated samples under VRS and CRS in the bootstrap-MPI stage. Unfortunately, due to the limitation of the software, the bootstrap-MPI under the VRS and CRS cannot be calculated simultaneously which means that the bias under VRS and CRS are different. Therefore, the enhance decomposition to decompose bootstrap-MPI was not chose at this stage. The PTEC and SEC thus cannot be obtained at this stage. In the future, how to calculate the bootstrap-MPI under the VRS and CRS using the same repeated samples would be an interesting research topic.

In this paper, panel data of provincial cross-sections of China was collected. The provincial data can only be obtained from the statistical yearbooks, where exact figures for labor force and draft animals of crop production could not be attained directly. We utilized the proportion of agricultural sector output in total value to calculate the labor force in crop farming and draft animal owned by households to represent the draft animal input. These index selections may lead to some bias in the measurement of the labor force input and draft animal input. However, we think it is a feasible solution to the solve the data lack problem. In the future, household surveys at a large scale should be strengthened to provide more accurate input data.

\section{Conclusion}

By combining the three-stage MPI and the Bootstrap-MPI, we measured the changes in TFP of crop production in 31 provinces/ autonomous regions in China from 1999 to 2008. The four external environment variables, including urbanization, farmers' economic situation, human resource levels, and natural disasters, and other random factors all had a significant impact on the generation of crop production input redundancy. The random factors were the dominant factors. Through the measurement of TFP using adjusted data, it was found that the traditional MPI model underestimated the TFP and its decomposition (TC index and TEC index). The measurement in the third stage showed that the annual average growth rate in the TFP of crop production was 7.6\%. After ratification with the bootstrap method, the MPI showed a large fluctuation compared with the estimation at the third stage, and the samples all passed the $5 \%$ confidence test. As for the decomposed efficiency, the fluctuation amplitude of the TEC index became smaller compared with the third stage; the variation trend in the TC index was the same as that of the MPI, and its fluctuation amplitude was larger compared with the third stage.

After rectification with the bootstrap method, the TFP of China's crop production increased by $6.1 \%$ in $1999-2008$, showing a trend of improvement. However, the productivity decreased between 2000 and 2002 and 2006 and 2007. Through the composition of TFP, it can be seen that the technical efficiency decreased by $0.1 \%$ between 1999 and 2008, with the variation range between $-1.2 \%$ and $1.0 \%$; the TC index of crop production improved by $6.2 \%$, with a large fluctuation amplitude. Structurally, the growth in TFP of China's crop production significantly depended on technical progress instead of an improvement in technical efficiency.

\section{Acknowledgements}

This project was supported by the Science and Technology Service Network Initiative (Grant No. KFJ-EW-STS-058) and the National Natural Science Foundation of China (Grant No. 41501192).

\section{Appendices}

Table A.1

Changes in efficiency of crop production in China at province level from 1999 to 2008 (Unit: \%).

\begin{tabular}{|c|c|c|c|c|c|c|c|c|c|}
\hline Regions & $1999 / 00$ & $2000 / 01$ & $2001 / 02$ & $2002 / 03$ & $2003 / 04$ & $2004 / 05$ & $2005 / 06$ & $2006 / 07$ & $2007 / 08$ \\
\hline Beijing & $\begin{array}{l}20.99^{* *} \\
{[1.20,1.23]}\end{array}$ & $\begin{array}{l}-5.28^{* *} \\
{[0.94,0.95]}\end{array}$ & $\begin{array}{l}-4.70^{* *} \\
{[0.95,0.96]}\end{array}$ & $\begin{array}{l}22.77^{* *} \\
{[1.22,1.24]}\end{array}$ & $\begin{array}{l}13.30^{* *} \\
{[1.12,1.14]}\end{array}$ & $\begin{array}{l}5.73^{* *} \\
{[1.05,1.07]}\end{array}$ & $\begin{array}{l}-2.89 * * \\
{[0.97,0.98]}\end{array}$ & $\begin{array}{l}-5.33^{* *} \\
{[0.94,0.95]}\end{array}$ & $\begin{array}{l}13.63^{* *} \\
{[1.13,1.14]}\end{array}$ \\
\hline Tianjin & $\begin{array}{l}23.71^{* *} \\
{[1.23,1.24]}\end{array}$ & $\begin{array}{l}-4.85^{* *} \\
{[0.95,0.95]}\end{array}$ & $\begin{array}{l}-3.67^{* *} \\
{[0.96,0.97]}\end{array}$ & $\begin{array}{l}27.06^{* *} \\
{[1.26,1.28]}\end{array}$ & $\begin{array}{l}14.78^{* *} \\
{[1.13,1.16]}\end{array}$ & $\begin{array}{l}5.93^{* *} \\
{[1.05,1.07]}\end{array}$ & $\begin{array}{l}-3.93^{* *} \\
{[0.95,0.97]}\end{array}$ & $\begin{array}{l}-5.35^{* *} \\
{[0.94,0.95]}\end{array}$ & $\begin{array}{l}15.55^{* *} \\
{[1.15,1.16]}\end{array}$ \\
\hline Hebei & $\begin{array}{l}7.50^{* *} \\
{[1.06,1.08]}\end{array}$ & $\begin{array}{l}-0.86^{* *} \\
{[0.98,1.00]}\end{array}$ & $\begin{array}{l}2.98^{* *} \\
{[1.02,1.04]}\end{array}$ & $\begin{array}{l}-6.19 * * \\
{[0.93,0.94]}\end{array}$ & $\begin{array}{l}19.08^{* *} \\
{[1.18,1.20]}\end{array}$ & $\begin{array}{l}6.94^{* *} \\
{[1.06,1.08]}\end{array}$ & $\begin{array}{l}6.40^{* *} \\
{[1.06,1.07]}\end{array}$ & $\begin{array}{l}1.58^{* *} \\
{[1.01,1.02]}\end{array}$ & $\begin{array}{l}9.77^{* *} \\
{[1.09,1.11]}\end{array}$ \\
\hline
\end{tabular}


Table A.1 (continued)

\begin{tabular}{|c|c|c|c|c|c|c|c|c|c|}
\hline Regions & $1999 / 00$ & $2000 / 01$ & $2001 / 02$ & $2002 / 03$ & $2003 / 04$ & $2004 / 05$ & $2005 / 06$ & $2006 / 07$ & $2007 / 08$ \\
\hline \multirow[t]{2}{*}{ Shanxi } & $11.31^{* *}$ & $-4.88^{* *}$ & $1.04^{* *}$ & $18.07^{* *}$ & $12.14^{* *}$ & $1.54^{* *}$ & $-0.77^{* *}$ & $0.85^{* *}$ & $9.56^{* *}$ \\
\hline & {$[1.10,1.13]$} & {$[0.93,0.96]$} & {$[1.01,1.02]$} & {$[1.17,1.19]$} & {$[1.11,1.13]$} & {$[1.01,1.02]$} & {$[0.99,1.00]$} & {$[1.00,1.01]$} & {$[1.09,1.10]$} \\
\hline Inner & $12.07^{* *}$ & $-4.04^{* *}$ & -0.09 & $18.02^{* *}$ & $18.32^{* *}$ & $4.43^{* *}$ & $10.14^{* *}$ & $-8.68^{* *}$ & $18.19^{* *}$ \\
\hline Mongolia & {$[1.12,1.13]$} & {$[0.95,0.96]$} & {$[0.99,1.00]$} & {$[1.17,1.19]$} & {$[1.17,1.20]$} & {$[1.04,1.05]$} & {$[1.10,1.11]$} & {$[0.91,0.92]$} & {$[1.17,1.19]$} \\
\hline \multirow[t]{2}{*}{ Liaoning } & $13.43^{* *}$ & $-3.75^{* *}$ & $-4.79^{* *}$ & $23.18^{* *}$ & $18.93^{* *}$ & $7.40^{* *}$ & $8.09^{* *}$ & $-6.80^{* *}$ & $18.90^{* *}$ \\
\hline & {$[1.13,1.15]$} & {$[0.95,0.97]$} & {$[0.95,0.96]$} & {$[1.22,1.24]$} & {$[1.18,1.20]$} & {$[1.07,1.08]$} & {$[1.07,1.09]$} & {$[0.93,0.94]$} & {$[1.18,1.20]$} \\
\hline \multirow{2}{*}{ Jilin } & $16.09^{* *}$ & $-5.81^{* *}$ & $-4.92^{* *}$ & $28.67^{* *}$ & $15.90^{* *}$ & $4.93^{* *}$ & $5.48^{* *}$ & $-5.36^{* *}$ & $21.42^{* *}$ \\
\hline & {$[1.15,1.17]$} & {$[0.94,0.95]$} & {$[0.95,0.95]$} & {$[1.28,1.29]$} & {$[1.15,1.17]$} & {$[1.04,1.06]$} & {$[1.05,1.06]$} & {$[0.94,0.95]$} & {$[1.21,1.22]$} \\
\hline \multirow[t]{2}{*}{ Heilongjiang } & $13.40^{* *}$ & $-3.26^{* *}$ & $-3.23^{* *}$ & $26.87^{* *}$ & $11.15^{* *}$ & $4.19^{* *}$ & $3.99^{* *}$ & $-4.75^{* *}$ & $9.23^{* *}$ \\
\hline & {$[1.13,1.14]$} & {$[0.96,0.97]$} & {$[0.96,0.97]$} & {$[1.26,1.28]$} & {$[1.11,1.12]$} & {$[1.03,1.05]$} & {$[1.04,1.04]$} & {$[0.95,0.96]$} & {$[1.09,1.10]$} \\
\hline \multirow[t]{2}{*}{ Shanghai } & $17.69^{* *}$ & $-4.72^{* *}$ & $-5.01^{* *}$ & $28.53^{* *}$ & $9.32^{* *}$ & $3.73^{* *}$ & $-1.08^{* *}$ & $-5.56^{* *}$ & $15.04^{* *}$ \\
\hline & {$[1.17,1.19]$} & {$[0.94,0.96]$} & {$[0.95,0.95]$} & {$[1.28,1.30]$} & {$[1.08,1.10]$} & {$[1.03,1.04]$} & {$[0.98,1.00]$} & {$[0.94,0.95]$} & {$[1.15,1.16]$} \\
\hline \multirow[t]{2}{*}{ Jiangsu } & $11.85^{* *}$ & $9.99^{* *}$ & $4.37^{* *}$ & $-8.70^{* *}$ & $20.41^{* *}$ & $5.49^{* *}$ & $6.99^{* *}$ & $-0.33^{* *}$ & $20.60^{* *}$ \\
\hline & {$[1.12,1.12]$} & {$[1.09,1.10]$} & {$[1.04,1.05]$} & {$[0.91,0.92]$} & {$[1.20,1.21]$} & {$[1.05,1.06]$} & {$[1.07,1.07]$} & {$[0.99,1.00]$} & {$[1.20,1.21]$} \\
\hline \multirow[t]{2}{*}{ Zhejiang } & $18.46^{* *}$ & $-2.34^{* *}$ & $0.30[1.00,1.01]$ & $5.20^{* *}$ & $9.74^{* *}$ & $7.13^{* *}$ & $0.86^{* *}$ & $-1.16^{* *}$ & $8.78^{* *}$ \\
\hline & {$[1.17,1.22]$} & {$[0.96,0.98]$} & & {$[1.04,1.06]$} & {$[1.09,1.10]$} & {$[1.06,1.08]$} & {$[1.00,1.01]$} & {$[0.98,0.99]$} & {$[1.08,1.09]$} \\
\hline \multirow[t]{2}{*}{ Anhui } & $9.27^{* *}$ & $-3.17^{* *}$ & $1.67^{* *}$ & $11.48^{* *}$ & $14.06^{* *}$ & $1.60^{* *}$ & $4.74^{* *}$ & $-1.13^{* *}$ & $7.03^{* *}$ \\
\hline & {$[1.09,1.10]$} & {$[0.96,0.97]$} & {$[1.01,1.02]$} & {$[1.11,1.12]$} & {$[1.14,1.15]$} & {$[1.01,1.02]$} & {$[1.05,1.05]$} & {$[0.99,0.99]$} & {$[1.07,1.08]$} \\
\hline \multirow[t]{2}{*}{ Fujian } & $9.05^{* *}$ & $-2.17^{* *}$ & $-4.50^{* *}$ & $31.64^{* *}$ & $8.04^{* *}$ & $7.12^{* *}$ & $0.06[0.99,1.01]$ & $0.95^{* *}$ & $7.06^{* *}$ \\
\hline & {$[1.08,1.11]$} & {$[0.97,0.98]$} & {$[0.95,0.96]$} & {$[1.30,1.33]$} & {$[1.08,1.09]$} & {$[1.07,1.08]$} & & {$[1.01,1.01]$} & {$[1.06,1.08]$} \\
\hline \multirow[t]{2}{*}{ Jiangxi } & $-3.62^{* *}$ & $3.45^{* *}$ & $-1.54^{* *}$ & $23.64^{* *}$ & $12.04^{* *}$ & $3.61^{* *}$ & $2.09^{* *}$ & $0.03[1.00,1.00]$ & $9.74^{* *}$ \\
\hline & {$[0.96,0.97]$} & {$[1.03,1.04]$} & {$[0.98,0.99]$} & {$[1.23,1.24]$} & {$[1.12,1.12]$} & {$[1.03,1.04]$} & {$[1.02,1.02]$} & & {$[1.09,1.11]$} \\
\hline \multirow[t]{2}{*}{ Shandong } & $6.61^{* *}$ & $4.18^{* *}$ & $-0.26^{* *}$ & $16.52^{* *}$ & $14.34^{* *}$ & $21.90^{* *}$ & $5.13^{* *}$ & $5.09^{* *}$ & $9.30^{* *}$ \\
\hline & {$[1.06,1.07]$} & {$[1.04,1.04]$} & {$[1.00,1.00]$} & {$[1.16,1.17]$} & {$[1.14,1.15]$} & {$[1.22,1.22]$} & {$[1.05,1.05]$} & {$[1.05,1.05]$} & {$[1.09,1.09]$} \\
\hline \multirow[t]{2}{*}{ Henan } & $6.69 * *$ & $1.55[0.99,1.03]$ & $1.10^{* *}$ & $7.90^{* *}$ & $14.67^{* *}$ & $16.90^{* *}$ & $4.92^{* *}$ & $9.01^{* *}$ & $5.79 * *$ \\
\hline & {$[1.06,1.07]$} & & {$[1.01,1.02]$} & {$[1.07,1.09]$} & {$[1.14,1.16]$} & {$[1.16,1.19]$} & {$[1.04,1.05]$} & {$[1.08,1.10]$} & {$[1.05,1.07]$} \\
\hline \multirow[t]{2}{*}{ Hubei } & $2.38^{* *}$ & $-3.11^{* *}$ & -0.29 & $25.19^{* *}$ & $5.00^{* *}$ & $17.45^{* *}$ & $5.99^{* *}$ & $-1.93^{* *}$ & $6.92^{* *}$ \\
\hline & {$[1.02,1.03]$} & {$[0.96,0.97]$} & {$[0.99,1.00]$} & {$[1.24,1.27]$} & {$[1.04,1.06]$} & {$[1.17,1.18]$} & {$[1.06,1.06]$} & {$[0.98,0.98]$} & {$[1.06,1.08]$} \\
\hline Hunan & $6.08^{* *}$ & -0.28 & $1.49^{* *}$ & $23.84^{* *}$ & $3.61^{* *}$ & $9.65^{* *}$ & $2.25^{* *}$ & -0.17 & $-6.54^{* *}$ \\
\hline & {$[1.05,1.07]$} & {$[0.99,1.00]$} & {$[1.01,1.02]$} & {$[1.23,1.25]$} & {$[1.03,1.05]$} & {$[1.09,1.10]$} & {$[1.02,1.03]$} & {$[0.99,1.00]$} & {$[0.93,0.94]$} \\
\hline Guangdong & $2.10^{* *}$ & $-3.19^{* *}$ & $-1.94^{* *}$ & $32.58^{* *}$ & $8.55^{* *}$ & $17.33^{* *}$ & $9.03^{* *}$ & $0.66^{* *}$ & $-9.68^{* *}$ \\
\hline & {$[1.01,1.03]$} & {$[0.97,0.97]$} & {$[0.98,0.98]$} & {$[1.32,1.34]$} & {$[1.08,1.09]$} & {$[1.17,1.18]$} & {$[1.09,1.09]$} & {$[1.01,1.01]$} & {$[0.90,0.91]$} \\
\hline Guangxi & $2.99^{* *}$ & $-3.86^{* *}$ & $-3.47^{* *}$ & $34.65^{* *}$ & $5.53^{* *}$ & $7.37^{* *}$ & $0.41^{* *}$ & $0.70^{* *}$ & $-6.39^{* *}$ \\
\hline & {$[1.03,1.04]$} & {$[0.95,0.97]$} & {$[0.96,0.97]$} & {$[1.34,1.36]$} & {$[1.04,1.07]$} & {$[1.06,1.08]$} & {$[1.00,1.01]$} & {$[1.00,1.01]$} & {$[0.93,0.94]$} \\
\hline Hainan & $11.55^{* *}$ & $-4.41^{* *}$ & $-5.14^{* *}$ & $41.41^{* *}$ & $6.54^{* *}$ & $11.09^{* *}$ & $-6.15^{* *}$ & $-3.60^{* *}$ & $5.86^{* *}$ \\
\hline & {$[1.11,1.13]$} & {$[0.95,0.96]$} & {$[0.95,0.95]$} & {$[1.40,1.43]$} & {$[1.05,1.08]$} & {$[1.11,1.12]$} & {$[0.93,0.95]$} & {$[0.96,0.97]$} & {$[1.05,1.06]$} \\
\hline Chongqing & $12.69^{* *}$ & $-4.48^{* *}$ & $-2.49^{* *}$ & $39.08^{* *}$ & $6.61^{* *}$ & $6.89^{* *}$ & $-1.43^{* *}$ & $2.70^{* *}$ & $-7.58^{* *}$ \\
\hline & {$[1.12,1.13]$} & {$[0.95,0.96]$} & {$[0.97,0.98]$} & {$[1.38,1.40]$} & {$[1.06,1.07]$} & {$[1.06,1.07]$} & {$[0.98,0.99]$} & {$[1.02,1.03]$} & {$[0.92,0.93]$} \\
\hline Sichuan & $-12.09^{* *}$ & $5.46^{* *}$ & $1.11^{* *}$ & $26.64^{* *}$ & $11.89^{* *}$ & $14.49^{* *}$ & $-0.90^{* *}$ & $2.09^{* *}$ & $-14.79^{* *}$ \\
\hline & {$[0.87,0.89]$} & {$[1.05,1.07]$} & {$[1.00,1.02]$} & {$[1.26,1.27]$} & {$[1.11,1.13]$} & {$[1.14,1.15]$} & {$[0.99,0.99]$} & {$[1.02,1.03]$} & {$[0.85,0.86]$} \\
\hline Guizhou & $1.92 * *$ & $0.51^{* *}$ & $-2.74^{* *}$ & $33.10^{* *}$ & $8.76^{* *}$ & $6.03^{* *}$ & $-4.21^{* *}$ & $3.06^{* *}$ & $-11.77^{* *}$ \\
\hline & {$[1.02,1.02]$} & {$[1.00,1.01]$} & {$[0.97,0.98]$} & {$[1.33,1.34]$} & {$[1.08,1.09]$} & {$[1.06,1.07]$} & {$[0.95,0.96]$} & {$[1.03,1.03]$} & {$[0.88,0.89]$} \\
\hline Yunnan & $5.80^{* *}$ & $-2.84^{* *}$ & $-3.20^{* *}$ & $28.06^{* *}$ & $6.18^{* *}$ & $7.84^{* *}$ & $-1.65^{* *}$ & $2.83^{* *}$ & $-10.69^{* *}$ \\
\hline & {$[1.05,1.06]$} & {$[0.96,0.98]$} & {$[0.96,0.97]$} & {$[1.27,1.29]$} & {$[1.06,1.07]$} & {$[1.07,1.09]$} & {$[0.98,0.99]$} & {$[1.03,1.03]$} & {$[0.89,0.90]$} \\
\hline Xizang & $10.42^{* *}$ & $-4.65^{* *}$ & $-5.85^{* *}$ & $44.98^{* *}$ & $6.89^{* *}$ & $6.53^{* *}$ & $-8.61^{* *}$ & $-1.53^{* *}$ & $5.86^{* *}$ \\
\hline & {$[1.10,1.11]$} & {$[0.95,0.96]$} & {$[0.94,0.95]$} & {$[1.44,1.46]$} & {$[1.05,1.08]$} & {$[1.06,1.07]$} & {$[0.91,0.92]$} & {$[0.98,0.99]$} & {$[1.05,1.06]$} \\
\hline Shaanxi & $12.83^{* *}$ & $-4.13^{* *}$ & $-5.13^{* *}$ & $36.24^{* *}$ & $5.36^{* *}$ & $7.56^{* *}$ & $-1.57^{* *}$ & $-1.66^{* *}$ & $-3.68^{* *}$ \\
\hline & {$[1.12,1.14]$} & {$[0.95,0.96]$} & {$[0.94,0.95]$} & {$[1.35,1.38]$} & {$[1.04,1.06]$} & {$[1.07,1.09]$} & {$[0.98,0.99]$} & {$[0.98,0.99]$} & {$[0.96,0.97]$} \\
\hline Gansu & $8.74^{* *}$ & $-3.84^{* *}$ & $-0.61^{* *}$ & $21.14^{* *}$ & $11.08^{* *}$ & $6.16^{* *}$ & $0.85^{* *}$ & $-2.15^{* *}$ & $6.73^{* *}$ \\
\hline & {$[1.08,1.09]$} & {$[0.96,0.97]$} & {$[0.99,1.00]$} & {$[1.21,1.22]$} & {$[1.10,1.12]$} & {$[1.06,1.07]$} & {$[1.00,1.01]$} & {$[0.97,0.98]$} & {$[1.06,1.07]$} \\
\hline Qinghai & $10.91^{* *}$ & $-1.55^{* *}$ & $-5.34^{* *}$ & $33.93^{* *}$ & $7.81^{* *}$ & $9.17^{* *}$ & $-9.87^{* *}$ & $-2.90^{* *}$ & $4.54^{* *}$ \\
\hline & {$[1.10,1.11]$} & {$[0.98,0.99]$} & {$[0.94,0.95]$} & {$[1.33,1.34]$} & {$[1.07,1.09]$} & {$[1.08,1.10]$} & {$[0.90,0.91]$} & {$[0.97,0.98]$} & {$[1.04,1.05]$} \\
\hline Ningxia & $18.26^{* *}$ & $-3.51^{* *}$ & $-5.78^{* *}$ & $26.50^{* *}$ & $12.42^{* *}$ & $6.84^{* *}$ & $-5.16^{* *}$ & $-4.42^{* *}$ & $8.66^{* *}$ \\
\hline & {$[1.18,1.19]$} & {$[0.96,0.97]$} & {$[0.94,0.95]$} & {$[1.26,1.27]$} & {$[1.11,1.13]$} & {$[1.06,1.07]$} & {$[0.94,0.95]$} & {$[0.95,0.96]$} & {$[1.08,1.09]$} \\
\hline Xinjiang & $12.57^{* *}$ & $-3.69^{* *}$ & $-6.84^{* *}$ & $35.16^{* *}$ & $9.52^{* *}$ & $9.24^{* *}$ & $5.04^{* *}$ & $-4.43^{* *}$ & $22.03^{* *}$ \\
\hline & {$[1.12,1.13]$} & {$[0.96,0.97]$} & {$[0.93,0.94]$} & {$[1.34,1.36]$} & {$[1.09,1.10]$} & {$[1.09,1.10]$} & {$[1.04,1.06]$} & {$[0.95,0.96]$} & {$[1.21,1.23]$} \\
\hline Improvement & 29 & 5 & 7 & 29 & 31 & 31 & 17 & 11 & 23 \\
\hline No change & 0 & 0 & 0 & 0 & 0 & 0 & 0 & 0 & 0 \\
\hline Decline & 2 & 24 & 21 & 2 & 0 & 0 & 13 & 18 & 8 \\
\hline
\end{tabular}

Notes: double asterisks $\left(^{* *}\right)$ denote significant differences from unity at 0.05 .1000 bootstrap replications. Numbers greater than zero indicate improvements.

Table A.2

Changes in technical efficiency of crop production in China at province level from 1999 to 2008 (Unit: \%).

\begin{tabular}{|c|c|c|c|c|c|c|c|c|c|}
\hline Regions & $1999 / 00$ & $2000 / 01$ & $2001 / 02$ & $2002 / 03$ & $2003 / 04$ & $2004 / 05$ & $2005 / 06$ & $2006 / 07$ & $2007 / 08$ \\
\hline Beijing & $\begin{array}{l}-1.16 \\
{[0.97,1.02]}\end{array}$ & $0.90[0.99,1.03]$ & $\begin{array}{l}-0.11 \\
{[0.99,1.01]}\end{array}$ & $\begin{array}{l}-0.08 \\
{[0.98,1.03]}\end{array}$ & $\begin{array}{l}-0.18 \\
{[0.98,1.01]}\end{array}$ & $0.22[0.99,1.01]$ & $0.16[0.99,1.01]$ & $0.19[0.99,1.01]$ & $0.02[0.99,1.01]$ \\
\hline Tianjin & $\begin{array}{l}-0.08 \\
{[0.99,1.01]}\end{array}$ & $0.38[1.00,1.01]$ & $\begin{array}{l}-0.08 \\
{[0.99,1.01]}\end{array}$ & $\begin{array}{l}-0.27 \\
{[0.99,1.00]}\end{array}$ & $0.00[0.99,1.01]$ & $0.00[0.99,1.01]$ & $0.05[0.99,1.01]$ & $0.01[0.99,1.01]$ & $0.00[0.99,1.01]$ \\
\hline Hebei & $\begin{array}{l}-0.16 \\
{[0.99,1.01]}\end{array}$ & $0.30[0.99,1.01]$ & $\begin{array}{l}-0.19 \\
{[0.99,1.01]}\end{array}$ & $\begin{array}{l}-2.60^{* *} \\
{[0.96,0.98]}\end{array}$ & $\begin{array}{l}-0.03 \\
{[0.99,1.01]}\end{array}$ & $\begin{array}{l}-1.02^{* *} \\
{[0.98,1.00]}\end{array}$ & $\begin{array}{l}1.77^{* *} \\
{[1.01,1.02]}\end{array}$ & $\begin{array}{l}-0.85^{* *} \\
{[0.99,1.00]}\end{array}$ & $\begin{array}{l}2.19^{* *} \\
{[1.01,1.05]}\end{array}$ \\
\hline Shanxi & $\begin{array}{l}-1.42 \\
{[0.97,1.04]}\end{array}$ & $1.26[0.97,1.03]$ & $0.12[0.99,1.01]$ & $\begin{array}{l}-0.18 \\
{[0.99,1.01]}\end{array}$ & $\begin{array}{l}-0.53 \\
{[0.98,1.01]}\end{array}$ & $0.64[0.99,1.02]$ & $\begin{array}{l}-0.13 \\
{[0.99,1.02]}\end{array}$ & $0.26[0.99,1.01]$ & $\begin{array}{l}-0.43 \\
{[0.99,1.00]}\end{array}$ \\
\hline
\end{tabular}


Table A.2 (continued)

\begin{tabular}{|c|c|c|c|c|c|c|c|c|c|}
\hline Regions & $1999 / 00$ & $2000 / 01$ & $2001 / 02$ & $2002 / 03$ & $2003 / 04$ & $2004 / 05$ & $2005 / 06$ & $2006 / 07$ & $2007 / 08$ \\
\hline $\begin{array}{l}\text { Inner } \\
\text { Mongolia }\end{array}$ & $\begin{array}{l}-3.42^{* *} \\
{[0.96,0.98]}\end{array}$ & $\begin{array}{l}2.71^{* *} \\
{[1.02,1.03]}\end{array}$ & $\begin{array}{l}1.25^{* *} \\
{[1.01,1.02]}\end{array}$ & $0.06[0.99,1.02]$ & $\begin{array}{l}-0.40 \\
{[0.98,1.01]}\end{array}$ & $0.14[0.99,1.01]$ & $0.42[1.00,1.01]$ & $\begin{array}{l}-0.15 \\
{[0.99,1.01]}\end{array}$ & $\begin{array}{l}-0.27 \\
{[0.99,1.01]}\end{array}$ \\
\hline Liaoning & $\begin{array}{l}-1.15 \\
{[0.97,1.02]}\end{array}$ & $0.98[0.98,1.03]$ & $\begin{array}{l}-0.21 \\
{[0.99,1.02]}\end{array}$ & $\begin{array}{l}-0.11 \\
{[0.98,1.02]}\end{array}$ & $\begin{array}{l}-0.65 \\
{[0.97,1.01]}\end{array}$ & $0.72[1.00,1.02]$ & $0.07[0.99,1.01]$ & $\begin{array}{l}-0.06 \\
{[0.99,1.01]}\end{array}$ & $\begin{array}{l}-0.18 \\
{[0.98,1.01]}\end{array}$ \\
\hline Jilin & $0.41[0.99,1.02]$ & $0.43[0.99,1.01]$ & $0.16[1.00,1.01]$ & $\begin{array}{l}-0.62^{* *} \\
{[0.98,1.00]}\end{array}$ & $\begin{array}{l}-0.82 \\
{[0.98,1.00]}\end{array}$ & $\begin{array}{l}-0.31 \\
{[0.99,1.01]}\end{array}$ & $\begin{array}{l}-0.66^{* *} \\
{[0.99,1.00]}\end{array}$ & $\begin{array}{l}2.06^{* *} \\
{[1.01,1.03]}\end{array}$ & $\begin{array}{l}-0.58^{* *} \\
{[0.99,1.00]}\end{array}$ \\
\hline Heilongjiang & $0.03[0.99,1.01]$ & $0.08[0.99,1.01]$ & $\begin{array}{l}-1.84^{* *} \\
{[0.98,0.98]}\end{array}$ & $\begin{array}{l}0.62^{* *} \\
{[1.00,1.01]}\end{array}$ & $\begin{array}{l}-1.76^{* *} \\
{[0.98,0.99]}\end{array}$ & $\begin{array}{l}-2.36^{* *} \\
{[0.97,0.98]}\end{array}$ & $\begin{array}{l}-0.66^{* *} \\
{[0.99,1.00]}\end{array}$ & $\begin{array}{l}0.80^{* *} \\
{[1.00,1.01]}\end{array}$ & $0.68[1.00,1.01]$ \\
\hline Shanghai & $\begin{array}{l}-1.02 \\
{[0.97,1.03]}\end{array}$ & $0.82[0.97,1.02]$ & $\begin{array}{l}-0.08 \\
{[0.98,1.01]}\end{array}$ & $\begin{array}{l}-0.02 \\
{[0.99,1.02]}\end{array}$ & $\begin{array}{l}-0.68 \\
{[0.98,1.02]}\end{array}$ & $0.51[0.99,1.02]$ & $0.00[0.99,1.01]$ & $0.10[0.99,1.01]$ & $\begin{array}{l}-0.15 \\
{[0.98,1.01]}\end{array}$ \\
\hline Jiangsu & $\begin{array}{l}-1.62 \\
{[0.97,1.04]}\end{array}$ & $1.26[0.96,1.04]$ & $\begin{array}{l}-0.03 \\
{[0.98,1.02]}\end{array}$ & $\begin{array}{l}-0.34 \\
{[0.98,1.02]}\end{array}$ & $\begin{array}{l}-0.32 \\
{[0.98,1.03]}\end{array}$ & $0.39[0.97,1.02]$ & $\begin{array}{l}-0.12 \\
{[0.99,1.01]}\end{array}$ & $0.34[0.99,1.01]$ & $\begin{array}{l}-0.39 \\
{[0.99,1.01]}\end{array}$ \\
\hline Zhejiang & $\begin{array}{l}-1.09 \\
{[0.96,1.06]}\end{array}$ & $1.13[0.94,1.03]$ & $0.06[0.98,1.01]$ & $\begin{array}{l}-0.53 \\
{[0.98,1.01]}\end{array}$ & $\begin{array}{l}-0.18 \\
{[0.98,1.01]}\end{array}$ & $0.44[0.99,1.02]$ & $\begin{array}{l}-0.16 \\
{[0.98,1.01]}\end{array}$ & $0.25[0.98,1.02]$ & $\begin{array}{l}-0.46 \\
{[0.98,1.01]}\end{array}$ \\
\hline Anhui & $\begin{array}{l}-0.78 \\
{[0.98,1.02]}\end{array}$ & $0.27[0.98,1.02]$ & $0.32[0.99,1.01]$ & $\begin{array}{l}-0.43 \\
{[0.98,1.02]}\end{array}$ & $\begin{array}{l}-0.38 \\
{[0.98,1.02]}\end{array}$ & $0.47[0.98,1.02]$ & $0.17[0.99,1.01]$ & $\begin{array}{l}-0.05 \\
{[0.99,1.01]}\end{array}$ & $\begin{array}{l}-0.20 \\
{[0.99,1.01]}\end{array}$ \\
\hline Fujian & $\begin{array}{l}-0.80 \\
{[0.98,1.03]}\end{array}$ & $0.80[0.97,1.03]$ & $\begin{array}{l}-0.10 \\
{[0.99,1.01]}\end{array}$ & $\begin{array}{l}-0.33 \\
{[0.99,1.02]}\end{array}$ & $\begin{array}{l}-0.73 \\
{[0.98,1.03]}\end{array}$ & $0.64[0.98,1.02]$ & $0.18[0.98,1.02]$ & $\begin{array}{l}-0.01 \\
{[0.99,1.01]}\end{array}$ & $0.17[0.98,1.01]$ \\
\hline Jiangxi & $\begin{array}{l}-5.59^{* *} \\
{[0.93,0.95]}\end{array}$ & $\begin{array}{l}5.99^{* *} \\
{[1.05,1.07]}\end{array}$ & $\begin{array}{l}-1.42^{* *} \\
{[0.98,0.99]}\end{array}$ & $0.23[1.00,1.01]$ & $\begin{array}{l}-4.64^{* *} \\
{[0.95,0.96]}\end{array}$ & $\begin{array}{l}2.33^{* *} \\
{[1.02,1.03]}\end{array}$ & $\begin{array}{l}1.15^{* *} \\
{[1.01,1.02]}\end{array}$ & $\begin{array}{l}-0.76^{* *} \\
{[0.99,1.00]}\end{array}$ & $\begin{array}{l}-0.12 \\
{[0.99,1.01]}\end{array}$ \\
\hline Shandong & $\begin{array}{l}-0.61 \\
{[0.98,1.01]}\end{array}$ & $0.43[0.99,1.02]$ & $0.20[1.00,1.01]$ & $\begin{array}{l}-0.21 \\
{[0.99,1.01]}\end{array}$ & $\begin{array}{l}-0.75 \\
{[0.98,1.04]}\end{array}$ & $0.55[0.97,1.02]$ & $0.25[0.99,1.01]$ & $\begin{array}{l}-0.15 \\
{[0.99,1.01]}\end{array}$ & $\begin{array}{l}-0.58 \\
{[0.98,1.02]}\end{array}$ \\
\hline Henan & $\begin{array}{l}-0.96 \\
{[0.97,1.04]}\end{array}$ & $1.00[0.97,1.02]$ & $\begin{array}{l}-0.41 \\
{[0.99,1.00]}\end{array}$ & $0.06[0.99,1.02]$ & $\begin{array}{l}-0.24 \\
{[0.98,1.02]}\end{array}$ & $\begin{array}{l}-0.01 \\
{[0.99,1.01]}\end{array}$ & $0.14[0.99,1.01]$ & $0.10[0.99,1.01]$ & $\begin{array}{l}-0.33 \\
{[0.98,1.01]}\end{array}$ \\
\hline Hubei & $\begin{array}{l}-0.77 \\
{[0.98,1.01]}\end{array}$ & $0.45[0.98,1.02]$ & $0.01[0.99,1.01]$ & $\begin{array}{l}-0.18 \\
{[0.98,1.02]}\end{array}$ & $\begin{array}{l}-5.62^{* *} \\
{[0.92,0.95]}\end{array}$ & $\begin{array}{l}6.04^{* *} \\
{[1.04,1.08]}\end{array}$ & $0.20[0.99,1.01]$ & $\begin{array}{l}-0.27 \\
{[0.99,1.01]}\end{array}$ & $0.12[0.99,1.01]$ \\
\hline Hunan & $\begin{array}{l}-1.66^{* *} \\
{[0.98,0.99]}\end{array}$ & $0.45[1.00,1.01]$ & $\begin{array}{l}-0.27 \\
{[0.99,1.00]}\end{array}$ & $\begin{array}{l}1.37^{* *} \\
{[1.01,1.02]}\end{array}$ & $\begin{array}{l}-4.64^{* *} \\
{[0.95,0.96]}\end{array}$ & $\begin{array}{l}1.61^{* *} \\
{[1.01,1.02]}\end{array}$ & $\begin{array}{l}1.08^{* *} \\
{[1.00,1.02]}\end{array}$ & $\begin{array}{l}-1.01^{* *} \\
{[0.98,1.00]}\end{array}$ & $\begin{array}{l}-5.86^{* *} \\
{[0.94,0.95]}\end{array}$ \\
\hline Guangdong & $\begin{array}{l}-0.97 \\
{[0.96,1.01]}\end{array}$ & $1.09[1.00,1.03]$ & $\begin{array}{l}-0.28 \\
{[0.98,1.01]}\end{array}$ & $\begin{array}{l}-0.34 \\
{[0.98,1.02]}\end{array}$ & $\begin{array}{l}-0.18 \\
{[0.98,1.01]}\end{array}$ & $0.41[0.98,1.02]$ & $\begin{array}{l}-0.07 \\
{[0.99,1.01]}\end{array}$ & $0.32[0.99,1.01]$ & $\begin{array}{l}-0.34 \\
{[0.98,1.01]}\end{array}$ \\
\hline Guangxi & $\begin{array}{l}-0.01 \\
{[0.99,1.02]}\end{array}$ & $0.34[0.99,1.03]$ & $0.10[0.99,1.01]$ & $\begin{array}{l}-0.20 \\
{[0.99,1.01]}\end{array}$ & $\begin{array}{l}-0.51 \\
{[0.97,1.01]}\end{array}$ & $0.79[0.99,1.02]$ & $0.02[0.99,1.01]$ & $\begin{array}{l}-0.32 \\
{[0.98,1.01]}\end{array}$ & $0.13[0.99,1.02]$ \\
\hline Hainan & $\begin{array}{l}-0.67 \\
{[0.98,1.02]}\end{array}$ & $0.59[0.98,1.02]$ & $\begin{array}{l}-0.21 \\
{[0.99,1.01]}\end{array}$ & $\begin{array}{l}-0.29 \\
{[0.98,1.02]}\end{array}$ & $\begin{array}{l}-0.14 \\
{[0.97,1.02]}\end{array}$ & $0.44[0.99,1.02]$ & $\begin{array}{l}-0.11 \\
{[0.99,1.01]}\end{array}$ & $0.16[0.99,1.01]$ & $\begin{array}{l}-0.34 \\
{[0.97,1.01]}\end{array}$ \\
\hline Chongqing & $\begin{array}{l}-0.35 \\
{[0.99,1.00]}\end{array}$ & $\begin{array}{l}-0.59 \\
{[0.99,1.00]}\end{array}$ & $0.40[1.00,1.01]$ & $\begin{array}{l}-0.40 \\
{[0.99,1.00]}\end{array}$ & $\begin{array}{l}-1.16^{* *} \\
{[0.98,0.99]}\end{array}$ & $\begin{array}{l}1.24^{* *} \\
{[1.01,1.02]}\end{array}$ & $0.27[0.99,1.02]$ & $0.34[0.99,1.01]$ & $\begin{array}{l}-0.54 \\
{[0.99,1.00]}\end{array}$ \\
\hline Sichuan & $\begin{array}{l}-9.04^{* *} \\
{[0.90,0.92]}\end{array}$ & $\begin{array}{l}8.87^{* *} \\
{[1.08,1.09]}\end{array}$ & $\begin{array}{l}0.49^{* *} \\
{[1.00,1.01]}\end{array}$ & $\begin{array}{l}-3.40^{* *} \\
{[0.96,0.97]}\end{array}$ & $\begin{array}{l}2.03^{* *} \\
{[1.01,1.03]}\end{array}$ & $\begin{array}{l}1.29^{* *} \\
{[1.00,1.02]}\end{array}$ & $\begin{array}{l}-0.98^{* *} \\
{[0.99,0.99]}\end{array}$ & $\begin{array}{l}1.59^{* *} \\
{[1.01,1.03]}\end{array}$ & $\begin{array}{l}-0.84^{* *} \\
{[0.98,1.00]}\end{array}$ \\
\hline Guizhou & $\begin{array}{l}-4.30^{* *} \\
{[0.95,0.96]}\end{array}$ & $\begin{array}{l}3.04^{* *} \\
{[1.02,1.04]}\end{array}$ & $\begin{array}{l}-2.68^{* *} \\
{[0.97,0.98]}\end{array}$ & $\begin{array}{l}2.25^{* *} \\
{[1.02,1.03]}\end{array}$ & $0.15[0.99,1.01]$ & $\begin{array}{l}1.31^{* *} \\
{[1.01,1.02]}\end{array}$ & $0.32[1.00,1.01]$ & $\begin{array}{l}-0.73^{* *} \\
{[0.99,1.00]}\end{array}$ & $\begin{array}{l}-0.84^{* *} \\
{[0.99,1.00]}\end{array}$ \\
\hline Yunnan & $\begin{array}{l}0.64^{* *} \\
{[1.00,1.01]}\end{array}$ & $\begin{array}{l}-1.71^{* *} \\
{[0.98,0.99]}\end{array}$ & $\begin{array}{l}0.90^{* *} \\
{[1.00,1.01]}\end{array}$ & $\begin{array}{l}-2.55^{* *} \\
{[0.97,0.98]}\end{array}$ & $0.61[1.00,1.02]$ & $\begin{array}{l}1.56^{* *} \\
{[1.01,1.02]}\end{array}$ & $\begin{array}{l}0.72^{* *} \\
{[1.00,1.01]}\end{array}$ & $0.47[1.00,1.01]$ & $\begin{array}{l}-0.83^{* *} \\
{[0.99,1.00]}\end{array}$ \\
\hline Xizang & $\begin{array}{l}-0.75 \\
{[0.98,1.01]}\end{array}$ & $0.70[0.99,1.02]$ & $\begin{array}{l}-0.30 \\
{[0.98,1.01]}\end{array}$ & $\begin{array}{l}-0.23 \\
{[0.99,1.01]}\end{array}$ & $\begin{array}{l}-0.27 \\
{[0.99,1.02]}\end{array}$ & $0.18[0.99,1.01]$ & $0.25[0.99,1.01]$ & $0.00[0.99,1.01]$ & $\begin{array}{l}-0.09 \\
{[0.99,1.01]}\end{array}$ \\
\hline Shaanxi & $\begin{array}{l}-0.58 \\
{[0.99,1.00]}\end{array}$ & $0.20[0.99,1.01]$ & $\begin{array}{l}-0.97^{* *} \\
{[0.98,1.00]}\end{array}$ & $0.66[1.00,1.02]$ & $0.12[0.99,1.01]$ & $0.10[0.99,1.01]$ & $0.13[0.99,1.01]$ & $0.02[0.99,1.01]$ & $\begin{array}{l}-0.41 \\
{[0.98,1.01]}\end{array}$ \\
\hline Gansu & $\begin{array}{l}-0.81^{* *} \\
{[0.99,1.00]}\end{array}$ & $\begin{array}{l}-1.63^{* *} \\
{[0.98,0.99]}\end{array}$ & $\begin{array}{l}1.75^{* *} \\
{[1.01,1.02]}\end{array}$ & $\begin{array}{l}-1.45^{* *} \\
{[0.98,0.99]}\end{array}$ & $\begin{array}{l}-1.16^{* *} \\
{[0.98,1.00]}\end{array}$ & $\begin{array}{l}2.26^{* *} \\
{[1.01,1.03]}\end{array}$ & $\begin{array}{l}-0.14 \\
{[0.99,1.00]}\end{array}$ & $\begin{array}{l}-1.56^{* *} \\
{[0.98,0.99]}\end{array}$ & $0.44[1.00,1.01]$ \\
\hline Qinghai & $\begin{array}{l}-1.23^{* *} \\
{[0.98,1.00]}\end{array}$ & $\begin{array}{l}1.23^{* *} \\
{[1.00,1.02]}\end{array}$ & $\begin{array}{l}-0.07 \\
{[1.00,1.00]}\end{array}$ & $\begin{array}{l}-0.83^{* *} \\
{[0.99,1.00]}\end{array}$ & $\begin{array}{l}-0.14 \\
{[0.99,1.01]}\end{array}$ & $\begin{array}{l}0.92^{* *} \\
{[1.00,1.01]}\end{array}$ & $\begin{array}{l}-0.04 \\
{[0.99,1.01]}\end{array}$ & $\begin{array}{l}-0.06 \\
{[0.99,1.00]}\end{array}$ & $\begin{array}{l}-0.24 \\
{[0.99,1.00]}\end{array}$ \\
\hline Ningxia & $\begin{array}{l}3.40^{* *} \\
{[1.03,1.04]}\end{array}$ & $\begin{array}{l}-0.91^{* *} \\
{[0.98,1.00]}\end{array}$ & $\begin{array}{l}-1.86^{* *} \\
{[0.98,0.99]}\end{array}$ & $0.45[1.00,1.01]$ & $0.40[1.00,1.01]$ & $\begin{array}{l}0.74^{* *} \\
{[1.00,1.01]}\end{array}$ & $\begin{array}{l}1.16^{* *} \\
{[1.01,1.02]}\end{array}$ & $\begin{array}{l}-0.17 \\
{[0.99,1.01]}\end{array}$ & $0.07[0.99,1.01]$ \\
\hline Xinjiang & $0.12[1.00,1.01]$ & $\begin{array}{l}-0.37 \\
{[0.99,1.00]}\end{array}$ & $\begin{array}{l}0.77^{* *} \\
{[1.00,1.01]}\end{array}$ & $\begin{array}{l}-0.12 \\
{[0.99,1.02]}\end{array}$ & $0.04[0.98,1.01]$ & $0.24[0.99,1.01]$ & $\begin{array}{l}-1.53^{* *} \\
{[0.98,0.99]}\end{array}$ & $\begin{array}{l}1.66^{* *} \\
{[1.01,1.02]}\end{array}$ & $\begin{array}{l}-0.15 \\
{[0.99,1.01]}\end{array}$ \\
\hline Improvement & 2 & 5 & 5 & 3 & 1 & 10 & 5 & 4 & 1 \\
\hline No change & 0 & 0 & 0 & 0 & 0 & 0 & 0 & 0 & 0 \\
\hline Decline & 7 & 3 & 5 & 6 & 6 & 2 & 4 & 5 & 5 \\
\hline
\end{tabular}

Notes: double asterisks $\left({ }^{* *}\right)$ denote significant differences from unity at 0.05 .1000 bootstrap replications. Numbers greater than zero indicate improvements.

Table A.3

Changes in technology of crop production in China at province level from 1999 to 2008 (Unit: \%).

\begin{tabular}{|c|c|c|c|c|c|c|c|c|c|}
\hline Regions & $1999 / 00$ & $2000 / 01$ & $2001 / 02$ & $2002 / 03$ & $2003 / 04$ & $2004 / 05$ & $2005 / 06$ & $2006 / 07$ & $2007 / 08$ \\
\hline Beijing & $\begin{array}{l}22.43^{* *} \\
{[1.21,1.24]}\end{array}$ & $\begin{array}{l}-6.12^{* *} \\
{[0.92,0.95]}\end{array}$ & $\begin{array}{l}-4.59^{* *} \\
{[0.94,0.96]}\end{array}$ & $\begin{array}{l}22.88^{* *} \\
{[1.21,1.24]}\end{array}$ & $\begin{array}{l}13.51^{* *} \\
{[1.12,1.15]}\end{array}$ & $\begin{array}{l}5.50^{* *} \\
{[1.05,1.07]}\end{array}$ & $\begin{array}{l}-3.05^{* *} \\
{[0.96,0.98]}\end{array}$ & $\begin{array}{l}-5.50^{* *} \\
{[0.94,0.95]}\end{array}$ & $\begin{array}{l}13.61^{* *} \\
{[1.13,1.14]}\end{array}$ \\
\hline Tianjin & $\begin{array}{l}23.81^{* *} \\
{[1.23,1.25]}\end{array}$ & $\begin{array}{l}-5.21^{* *} \\
{[0.94,0.95]}\end{array}$ & $\begin{array}{l}-3.59^{* *} \\
{[0.96,0.97]}\end{array}$ & $\begin{array}{l}27.40^{* *} \\
{[1.27,1.28]}\end{array}$ & $\begin{array}{l}14.79 \text { ** } \\
{[1.13,1.16]}\end{array}$ & $\begin{array}{l}5.94^{* *} \\
{[1.05,1.07]}\end{array}$ & $\begin{array}{l}-3.98^{* *} \\
{[0.95,0.97]}\end{array}$ & $\begin{array}{l}-5.36^{* *} \\
{[0.94,0.95]}\end{array}$ & $\begin{array}{l}15.55^{* *} \\
{[1.15,1.16]}\end{array}$ \\
\hline Hebei & $\begin{array}{l}7.67^{* *} \\
{[1.07,1.08]}\end{array}$ & $\begin{array}{l}-1.15^{* *} \\
{[0.98,1.00]}\end{array}$ & $\begin{array}{l}3.18^{* *} \\
{[1.02,1.04]}\end{array}$ & $\begin{array}{l}-3.68^{* *} \\
{[0.96,0.97]}\end{array}$ & $\begin{array}{l}19.11^{* *} \\
{[1.18,1.20]}\end{array}$ & $\begin{array}{l}8.04^{* *} \\
{[1.07,1.09]}\end{array}$ & $\begin{array}{l}4.55^{* *} \\
{[1.04,1.05]}\end{array}$ & $\begin{array}{l}2.44^{* *} \\
{[1.02,1.03]}\end{array}$ & $\begin{array}{l}7.42^{* *} \\
{[1.06,1.09]}\end{array}$ \\
\hline Shanxi & $\begin{array}{l}12.95^{* *} \\
{[1.10,1.14]}\end{array}$ & $\begin{array}{l}-6.05^{* *} \\
{[0.93,0.96]}\end{array}$ & $\begin{array}{l}0.92^{* *} \\
{[1.00,1.02]}\end{array}$ & $\begin{array}{l}18.29^{* *} \\
{[1.17,1.19]}\end{array}$ & $\begin{array}{l}12.74^{* *} \\
{[1.12,1.14]}\end{array}$ & $0.90[1.00,1.02]$ & $\begin{array}{l}-0.63 \\
{[0.98,1.00]}\end{array}$ & $\begin{array}{l}0.60^{* *} \\
{[1.00,1.02]}\end{array}$ & $\begin{array}{l}10.03^{* *} \\
{[1.09,1.11]}\end{array}$ \\
\hline
\end{tabular}


Table A.3 (continued)

\begin{tabular}{|c|c|c|c|c|c|c|c|c|c|}
\hline Regions & 1999/00 & $2000 / 01$ & $2001 / 02$ & $2002 / 03$ & $2003 / 04$ & $2004 / 05$ & $2005 / 06$ & $2006 / 07$ & $2007 / 08$ \\
\hline Inner & $16.04^{* *}$ & $-6.57^{* *}$ & $-1.32^{* *}$ & $17.96^{* *}$ & $18.81^{* *}$ & $4.28^{* *}$ & $9.68^{* *}$ & $-8.55^{* *}$ & $18.51^{* *}$ \\
\hline Mongolia & {$[1.15,1.17]$} & {$[0.93,0.94]$} & {$[0.98,0.99]$} & {$[1.17,1.19]$} & {$[1.17,1.21]$} & {$[1.03,1.05]$} & {$[1.09,1.10]$} & {$[0.91,0.92]$} & {$[1.18,1.19]$} \\
\hline \multirow[t]{2}{*}{ Liaoning } & $14.77^{* *}$ & $-4.67^{* *}$ & $-4.59^{* *}$ & $23.33^{* *}$ & $19.72^{* *}$ & $6.63^{* *}$ & $8.02^{* *}$ & $-6.75^{* *}$ & $19.12^{* *}$ \\
\hline & {$[1.13,1.16]$} & {$[0.94,0.97]$} & {$[0.94,0.96]$} & {$[1.21,1.25]$} & {$[1.18,1.22]$} & {$[1.06,1.08]$} & {$[1.07,1.09]$} & {$[0.92,0.94]$} & {$[1.18,1.20]$} \\
\hline \multirow[t]{2}{*}{ Jilin } & $15.63^{* *}$ & $-6.21^{* *}$ & $-5.07^{* *}$ & $29.47^{* *}$ & $16.86^{* *}$ & $5.26^{* *}$ & $6.18^{* *}$ & $-7.27^{* *}$ & $22.13^{* *}$ \\
\hline & {$[1.15,1.16]$} & {$[0.93,0.95]$} & {$[0.94,0.95]$} & {$[1.29,1.30]$} & {$[1.15,1.18]$} & {$[1.04,1.06]$} & {$[1.06,1.07]$} & {$[0.92,0.93]$} & {$[1.22,1.23]$} \\
\hline \multirow[t]{2}{*}{ Heilongjiang } & $13.37^{* *}$ & $-3.34^{* *}$ & $-1.42^{* *}$ & $26.09^{* *}$ & $13.15^{* *}$ & $6.71^{* *}$ & $4.68^{* *}$ & $-5.51^{* *}$ & $8.49^{* *}$ \\
\hline & {$[1.13,1.14]$} & {$[0.96,0.97]$} & {$[0.98,0.99]$} & {$[1.25,1.27]$} & {$[1.13,1.14]$} & {$[1.06,1.08]$} & {$[1.04,1.05]$} & {$[0.94,0.95]$} & {$[1.08,1.10]$} \\
\hline \multirow{2}{*}{ Shanghai } & $18.93^{* *}$ & $-5.47^{* *}$ & $-4.94^{* *}$ & $28.56^{* *}$ & $10.09^{* *}$ & $3.22^{* *}$ & -1.07 & $-5.65^{* *}$ & $15.22^{* *}$ \\
\hline & {$[1.16,1.20]$} & {$[0.93,0.97]$} & {$[0.94,0.96]$} & {$[1.28,1.30]$} & {$[1.07,1.12]$} & {$[1.02,1.05]$} & {$[0.98,1.00]$} & {$[0.93,0.95]$} & {$[1.14,1.17]$} \\
\hline \multirow[t]{2}{*}{ Jiangsu } & $13.75^{* *}$ & $8.67^{* *}$ & $4.42^{* *}$ & $-8.39^{* *}$ & $20.82^{* *}$ & $5.11^{* *}$ & $7.13^{* *}$ & -0.66 & $21.08^{* *}$ \\
\hline & {$[1.08,1.16]$} & {$[1.06,1.14]$} & {$[1.02,1.06]$} & {$[0.90,0.93]$} & {$[1.17,1.23]$} & {$[1.03,1.09]$} & {$[1.06,1.08]$} & {$[0.98,1.00]$} & {$[1.20,1.22]$} \\
\hline \multirow[t]{2}{*}{ Zhejiang } & $19.82^{* *}$ & -3.39 & $0.25[1.00,1.02]$ & $5.77^{* *}$ & $9.96^{* *}$ & $6.67^{* *}$ & $1.02[0.99,1.02]$ & $-1.40^{* *}$ & $9.29^{* *}$ \\
\hline & {$[1.15,1.22]$} & {$[0.95,1.02]$} & & {$[1.04,1.07]$} & {$[1.09,1.11]$} & {$[1.06,1.08]$} & & {$[0.97,1.00]$} & {$[1.08,1.10]$} \\
\hline \multirow[t]{2}{*}{ Anhui } & $10.15^{* *}$ & $-3.42^{* *}$ & $1.36^{* *}$ & $11.97^{* *}$ & $14.50^{* *}$ & $1.13[1.00,1.03]$ & $4.57^{* *}$ & -1.08 & $7.25^{* *}$ \\
\hline & {$[1.08,1.12]$} & {$[0.95,0.98]$} & {$[1.01,1.03]$} & {$[1.10,1.13]$} & {$[1.13,1.16]$} & & {$[1.04,1.06]$} & {$[0.98,1.00]$} & {$[1.06,1.08]$} \\
\hline \multirow[t]{2}{*}{ Fujian } & $9.95^{* *}$ & $-2.93^{* *}$ & $-4.40^{* *}$ & $32.08^{* *}$ & $8.85^{* *}$ & $6.45^{* *}$ & -0.11 & $0.96[1.00,1.02]$ & $6.88^{* *}$ \\
\hline & {$[1.08,1.11]$} & {$[0.95,1.00]$} & {$[0.95,0.97]$} & {$[1.31,1.33]$} & {$[1.06,1.10]$} & {$[1.05,1.09]$} & {$[0.99,1.01]$} & & {$[1.06,1.08]$} \\
\hline \multirow[t]{2}{*}{ Jiangxi } & $2.09^{* *}$ & $-2.40^{* *}$ & -0.11 & $23.36^{* *}$ & $17.50^{* *}$ & $1.25^{* *}$ & $0.92^{* *}$ & $0.80^{* *}$ & $9.88^{* *}$ \\
\hline & {$[1.02,1.03]$} & {$[0.97,0.98]$} & {$[0.99,1.00]$} & {$[1.22,1.24]$} & {$[1.17,1.18]$} & {$[1.01,1.02]$} & {$[1.00,1.01]$} & {$[1.00,1.01]$} & {$[1.09,1.11]$} \\
\hline \multirow[t]{2}{*}{ Shandong } & $7.27^{* *}$ & $3.74^{* *}$ & -0.46 & $16.77^{* *}$ & $15.23^{* *}$ & $21.26^{* *}$ & $4.86^{* *}$ & $5.25^{* *}$ & $9.96^{* *}$ \\
\hline & {$[1.06,1.08]$} & {$[1.02,1.05]$} & {$[0.99,1.00]$} & {$[1.16,1.18]$} & {$[1.11,1.17]$} & {$[1.19,1.26]$} & {$[1.04,1.06]$} & {$[1.04,1.06]$} & {$[1.07,1.12]$} \\
\hline \multirow[t]{2}{*}{ Henan } & $7.76^{* *}$ & $0.56[0.99,1.03]$ & $1.52^{* *}$ & $7.84^{* *}$ & $14.95^{* *}$ & $16.91^{* *}$ & $4.78^{* *}$ & $8.90^{* *}$ & $6.15^{* *}$ \\
\hline & {$[1.04,1.09]$} & & {$[1.01,1.02]$} & {$[1.06,1.09]$} & {$[1.14,1.16]$} & {$[1.15,1.19]$} & {$[1.04,1.06]$} & {$[1.08,1.10]$} & {$[1.05,1.07]$} \\
\hline \multirow[t]{2}{*}{ Hubei } & $3.19^{* *}$ & $-3.54^{* *}$ & -0.29 & $25.43^{* *}$ & $11.25^{* *}$ & $10.77^{* *}$ & $5.78^{* *}$ & $-1.66^{* *}$ & $6.79^{* *}$ \\
\hline & {$[1.01,1.04]$} & {$[0.95,0.98]$} & {$[0.99,1.01]$} & {$[1.23,1.27]$} & {$[1.11,1.13]$} & {$[1.09,1.12]$} & {$[1.05,1.07]$} & {$[0.98,0.99]$} & {$[1.06,1.08]$} \\
\hline \multirow[t]{2}{*}{ Hunan } & $7.88^{* *}$ & $-0.73^{* *}$ & $1.76^{* *}$ & $22.17^{* *}$ & $8.65^{* *}$ & $7.92^{* *}$ & $1.16^{* *}$ & $0.85^{* *}$ & $-0.72^{* *}$ \\
\hline & {$[1.07,1.08]$} & {$[0.99,1.00]$} & {$[1.01,1.02]$} & {$[1.21,1.23]$} & {$[1.08,1.09]$} & {$[1.07,1.08]$} & {$[1.00,1.02]$} & {$[1.00,1.02]$} & {$[0.98,1.00]$} \\
\hline \multirow[t]{2}{*}{ Guangdong } & $3.13^{* *}$ & $-4.21^{* *}$ & $-1.66^{* *}$ & $33.05^{* *}$ & $8.75^{* *}$ & $16.86^{* *}$ & $9.10^{* *}$ & $0.34[0.99,1.02]$ & $-9.37^{* *}$ \\
\hline & {$[1.01,1.05]$} & {$[0.94,0.97]$} & {$[0.97,1.00]$} & {$[1.30,1.34]$} & {$[1.07,1.10]$} & {$[1.16,1.19]$} & {$[1.08,1.10]$} & & {$[0.89,0.92]$} \\
\hline \multirow[t]{2}{*}{ Guangxi } & $3.01^{* *}$ & $-4.18^{* *}$ & $-3.56^{* *}$ & $34.93^{* *}$ & $6.08^{* *}$ & $6.53^{* *}$ & $0.39[1.00,1.01]$ & $1.04^{* *}$ & $-6.50^{* *}$ \\
\hline & {$[1.02,1.04]$} & {$[0.95,0.97]$} & {$[0.96,0.97]$} & {$[1.34,1.36]$} & {$[1.05,1.07]$} & {$[1.06,1.08]$} & & {$[1.00,1.02]$} & {$[0.93,0.94]$} \\
\hline Hainan & $12.33^{* *}$ & $-4.96^{* *}$ & $-4.94^{* *}$ & $41.85^{* *}$ & $6.69^{* *}$ & $10.61^{* *}$ & $-6.05^{* *}$ & $-3.75^{* *}$ & $6.23^{* *}$ \\
\hline & {$[1.10,1.14]$} & {$[0.94,0.96]$} & {$[0.94,0.96]$} & {$[1.40,1.44]$} & {$[1.05,1.08]$} & {$[1.09,1.12]$} & {$[0.93,0.95]$} & {$[0.96,0.97]$} & {$[1.05,1.08]$} \\
\hline Chongqing & $13.08^{* *}$ & $-3.91^{* *}$ & $-2.87^{* *}$ & $39.64^{* *}$ & $7.86^{* *}$ & $5.59^{* *}$ & $-1.69^{* *}$ & $2.36^{* *}$ & $-7.07^{* *}$ \\
\hline & {$[1.13,1.14]$} & {$[0.96,0.97]$} & {$[0.97,0.98]$} & {$[1.39,1.41]$} & {$[1.07,1.08]$} & {$[1.05,1.06]$} & {$[0.98,0.99]$} & {$[1.02,1.03]$} & {$[0.92,0.93]$} \\
\hline Sichuan & $-3.35^{* *}$ & $-3.13^{* *}$ & $0.61[1.00,1.01]$ & $31.09^{* *}$ & $9.67^{* *}$ & $13.04^{* *}$ & $0.09[1.00,1.01]$ & $0.49[1.00,1.01]$ & $-14.07^{* *}$ \\
\hline & {$[0.96,0.98]$} & {$[0.96,0.98]$} & & {$[1.30,1.32]$} & {$[1.09,1.10]$} & {$[1.12,1.14]$} & & & {$[0.85,0.87]$} \\
\hline Guizhou & $6.50^{* *}$ & $-2.45^{* *}$ & -0.05 & $30.17^{* *}$ & $8.60^{* *}$ & $4.66^{* *}$ & $-4.51^{* *}$ & $3.82^{* *}$ & $-11.02^{* *}$ \\
\hline & {$[1.06,1.07]$} & {$[0.97,0.98]$} & {$[0.99,1.00]$} & {$[1.29,1.31]$} & {$[1.08,1.09]$} & {$[1.04,1.05]$} & {$[0.95,0.96]$} & {$[1.03,1.04]$} & {$[0.88,0.90]$} \\
\hline Yunnan & $5.13^{* *}$ & $-1.14^{* *}$ & $-4.06^{* *}$ & $31.41^{* *}$ & $5.54^{* *}$ & $6.18^{* *}$ & $-2.35^{* *}$ & $2.35^{* *}$ & $-9.95^{* *}$ \\
\hline & {$[1.05,1.06]$} & {$[0.98,0.99]$} & {$[0.96,0.96]$} & {$[1.31,1.32]$} & {$[1.04,1.06]$} & {$[1.06,1.07]$} & {$[0.97,0.98]$} & {$[1.02,1.03]$} & {$[0.90,0.90]$} \\
\hline Xizang & $11.26^{* *}$ & $-5.30^{* *}$ & $-5.56^{* *}$ & $45.32^{* *}$ & $7.18^{* *}$ & $6.34^{* *}$ & $-8.84^{* *}$ & $-1.54^{* *}$ & $5.96^{* *}$ \\
\hline & {$[1.10,1.12]$} & {$[0.94,0.96]$} & {$[0.93,0.95]$} & {$[1.44,1.46]$} & {$[1.05,1.08]$} & {$[1.05,1.08]$} & {$[0.90,0.92]$} & {$[0.98,0.99]$} & {$[1.05,1.06]$} \\
\hline Shaanxi & $13.49^{* *}$ & $-4.32^{* *}$ & $-4.20^{* *}$ & $35.35^{* *}$ & $5.24^{* *}$ & $7.45^{* *}$ & $-1.69^{* *}$ & $-1.68^{* *}$ & $-3.28^{* *}$ \\
\hline & {$[1.13,1.14]$} & {$[0.95,0.96]$} & {$[0.95,0.96]$} & {$[1.34,1.36]$} & {$[1.04,1.06]$} & {$[1.07,1.09]$} & {$[0.98,0.99]$} & {$[0.98,0.99]$} & {$[0.96,0.98]$} \\
\hline Gansu & $9.64^{* *}$ & $-2.25^{* *}$ & $-2.33^{* *}$ & $22.92^{* *}$ & $12.39 * *$ & $3.81^{* *}$ & $1.00^{* *}$ & $-0.60^{* *}$ & $6.26^{* *}$ \\
\hline & {$[1.09,1.10]$} & {$[0.97,0.98]$} & {$[0.97,0.98]$} & {$[1.22,1.24]$} & {$[1.11,1.13]$} & {$[1.03,1.05]$} & {$[1.01,1.01]$} & {$[0.99,1.00]$} & {$[1.06,1.07]$} \\
\hline Qinghai & $12.30^{* *}$ & $-2.75^{* *}$ & $-5.27^{* *}$ & $35.05^{* *}$ & $7.96^{* *}$ & $8.17^{* * *}$ & $-9.83^{* *}$ & $-2.84^{* *}$ & $4.79^{* *}$ \\
\hline & {$[1.11,1.13]$} & {$[0.97,0.98]$} & {$[0.94,0.95]$} & {$[1.34,1.36]$} & {$[1.07,1.09]$} & {$[1.07,1.09]$} & {$[0.90,0.91]$} & {$[0.97,0.98]$} & {$[1.04,1.05]$} \\
\hline Ningxia & $14.37^{* *}$ & $-2.63^{* *}$ & $-4.00^{* *}$ & $25.94^{* *}$ & $11.96^{* *}$ & $6.05^{* *}$ & $-6.24^{* *}$ & $-4.26^{* *}$ & $8.59^{* *}$ \\
\hline & {$[1.14,1.15]$} & {$[0.97,0.98]$} & {$[0.96,0.96]$} & {$[1.25,1.27]$} & {$[1.11,1.13]$} & {$[1.05,1.07]$} & {$[0.93,0.94]$} & {$[0.95,0.96]$} & {$[1.08,1.09]$} \\
\hline Xinjiang & $12.44^{* *}$ & $-3.33^{* *}$ & $-7.55^{* *}$ & $35.33^{* *}$ & $9.48^{* *}$ & $8.97^{* *}$ & $6.67^{* *}$ & $-5.99^{* *}$ & $22.22^{* *}$ \\
\hline & {$[1.12,1.13]$} & {$[0.96,0.97]$} & {$[0.92,0.93]$} & {$[1.34,1.36]$} & {$[1.08,1.11]$} & {$[1.08,1.10]$} & {$[1.06,1.08]$} & {$[0.93,0.95]$} & {$[1.22,1.23]$} \\
\hline Improvement & 30 & 2 & 6 & 29 & 31 & 29 & 15 & 10 & 23 \\
\hline No change & 0 & 0 & 0 & 0 & 0 & 0 & 0 & 0 & 0 \\
\hline Decline & 1 & 27 & 19 & 2 & 0 & 0 & 10 & 16 & 8 \\
\hline
\end{tabular}

Notes: double asterisks $\left(^{* *}\right)$ denote significant differences from unity at 0.05 .1000 bootstrap replications. Numbers greater than zero indicate improvements.

\section{References}

Aigner, D.J., Amemiya, T., Poirier, D.J., 1976. On the estimation of production frontiers: maximum likelihood estimation of the parameters of a discontinuous density function. Int. Econ. Rev. 17, 377-396, 10.2307/2525708.

Aigner, D.J., Lovell, C.A.K., Schmidt, P., 1977. Formulation and estimation of stochastic frontier production function models. J. Econ. 6, 21-37.

Alene, A.D., 2010. Productivity growth and the effects of R\&D in African agriculture. Agric. Econ. 41, 223-238.

Arjomandi, A., Valadkhani, A., Harvie, C., 2011. Analysing productivity changes using the bootstrapped malmquist approach: the case of the iranian banking industry. Australas. Account. Bus. Finance J. 5, 35-56. Available at: http://mpra.ub.unimuenchen.de/50397/.

Banker, R.D., Morey, R.C., 1986. The use of categorical variables in data envelopment analysis. Manag. Sci. 32, 1613-1627.

Banker, R.D., Charnes, A., Cooper, W.W., 1984. Some models for estimating technical and scale inefficiencies in data envelopment analysis. Manag. Sci. 30, 1078-1092. http://dx.doi.org/10.1287/mnsc.30.9.1078.

Battese, G.E., Coelli, T.J., 1992. Frontier production functions, technical efficiency and panel data: with application to paddy farmers in India. J. Prod. Analysis 3, 153-169. http://dx.doi.org/10.1007/bf00158774.

Bhattacharyya, A., Lovell, C.A.K., Sahay, P., 1997. The impact of liberalization on the productive efficiency of Indian commercial banks. Eur. J. Operational Res. 98, 332-345. http://dx.doi.org/10.1016/S0377-2217(96)00351-7.

Brummer, B., Glauben, T., Lu, W., 2006. Policy reform and productivity change in Chinese agriculture: a distance function approach. J. Dev. Econ. 81, 61-79. http://dx.doi.org/10.1016/j.jdeveco.2005.04.009.

Cao, K.H., Birchenall, J.A., 2013. Agricultural productivity, structural change, and economic growth in post-reform China. J. Dev. Econ. 104, 165-180. http:// dx.doi.org/10.1016/j.jdeveco.2013.06.001.

Carter, C.A., Chen, J., Chu, B., 1999. Agricultural productivity growth in China: farm level versus national measurement. Work. Pap. 14, 53-71. 
Caves, D.W., Christensen, L.R., Diewert, W.E., 1982. The economic theory of index numbers and the measurement of input, output, and productivity. Econometrica 50, 1393-1414, 10.2307/1913388.

Charnes, A., Cooper, W.W., Rhodes, E., 1978. Measuring the efficiency of decision making units. Eur. J. Operational Res. 2, 429-444. http://dx.doi.org/10.1016/ 0377-2217(78)90138-8.

Chen, W., 2006. Productivity growth technical progress and efficiency change in Chinese agriculture 1990-2003. China Rural. Surv. 1, 18-23 (in Chinese).

Coelli, T.J., Rao, D.S.P., 2005. Total factor productivity growth in agriculture: a Malmquist index analysis of 93 countries, 1980-2000. Agric. Econ. 32, 115-134. http://dx.doi.org/10.1111/j.0169-5150.2004.00018.x.

Coelli, T.J., Rao, D.S.P., O'Donnell, C.J., Battese, G.E., 2005. Efficiency Measurement Using Data Envelopment Analysis (DEA). An Introduction to Efficiency and Productivity Analysis, second ed. Springer, New York. http://dx.doi.org/10.1007/ 978-1-4615-5493-6.

Deng, H.S., Huang, J.K., Xu, Z.G., Rozelle, S., 2010. Policy support and emerging farmer professional cooperatives in rural China. China Econ. Rev. 21, 495-507. http://dx.doi.org/10.1016/j.chieco.2010.04.009.

Deng, X.Z., Huang, J.K., Rozelle, S., Zhang, J.P., Li, Z.H., 2015. Impact of urbanization on cultivated land changes in China. Land Use Policy 45, 1-7. http://dx.doi.org 10.1016/j.landusepol.2015.01.007.

Esposti, R., 2011. Convergence and divergence in regional agricultural productivity growth: evidence from Italian regions, 1951-2002. Agricutural Econ. 42, 153-169. http://dx.doi.org/10.1111/j.1574-0862.2010.00508.x.

Fan, S.G., Zhang, X.B., 2002. Production and productivity growth in Chinese agriculture: new national and regional measures. Econ. Dev. Cult. Change 50, 819-838. http://dx.doi.org/10.1086/343136.

Fan, S.G., 1997. How Fast Have China's Agricultural Production and Productivity Really Been Growing?: New Measurement and Evidence. Eptd Discussion Papers 30. International Food Policy Research Institute (IFPRI). Available at: http:// www.ifpri.org/sites/default/files/publications/eptdp30.pdf (accessed 25.04.15.).

Fang, H., 2010. Research on technical efficiency of China's agricultural production: measurement, discovery and interpretation based on the provincial level. J. Agrotechnical Econ. 1, 34-41 (in Chinese).

Färe, R., Zhang, Z., 1994. Productivity growth, technical progress, and efficiency change in industrialized countries. Am. Econ. Rev. 84, 66-83.

Färe, R., Grosskopf, S., Lindgren, B., Roos, P., 1992. Productivity changes in Swedish pharamacies 1980-1989: a non-parametric Malmquist approach. J. Prod. Analysis 3, 85-101. http://dx.doi.org/10.1007/bf00158770.

Fried, H.O., Lovell, C.A.K., Eeckaut, P.V., 1993. Evaluating the performance of US credit unions. J. Bank. Finance 17, 251-265. http://dx.doi.org/10.1016/03784266(93)90031-8.

Fried, H.O., Lovell, C.A.K., Schmidt, S.S., Yaisawarng, S., 2002. Accounting for environmental effects and statistical noise in data envelopment analysis. J. Prod. Analysis 17, 157-174. http://dx.doi.org/10.1023/A:1013548723393.

Fried, H.O., Schmidt, S.S., Yaisawarng, S., 1999. Incorporating the operating environment into a nonparametric measure of technical efficiency. J. Prod. Analysis 12, 249-267. http://dx.doi.org/10.1023/A:1007800306752.

Grosskopf, S., 1996. Statistical inference and nonparametric efficiency: a selective survey. J. Prod. Analysis 7, 161-176. http://dx.doi.org/10.1007/Bf00157039.

Guo, J.H., Ni, M., Li, B.Y., 2010. Research on agricultural production efficiency based on three-stage DEA model. J. Quantitative Tech. Econ. 27-38.

Hayami, Y., 1969. Sources of agricultural productivity gap among selected countries. Am. J. Agric. Econ. 51, 564-575, 10.2307/1237909.

Headey, D., Alauddin, M., Rao, D.S.P., 2010. Explaining agricultural productivity growth: an international perspective. Agric. Econ. 41, 1-14. http://dx.doi.org 10.1111/j.1574-0862.2009.00420.x.

Hong, W., Cao, L., Hao, N., 2010. Trade Liberalization, domestic input and sustainability of agricultural TFP growth: a new perspective based on TFP growth structure. Agric. Agric. Sci. Procedia 1, 376-385. http://dx.doi.org/10.1016/ j.aaspro.2010.09.047.

Huang, J.K., Gao, L.L., Rozelle, S., 2012. The effect of off-farm employment on the decisions of households to rent out and rent in cultivated land in China. China Agric. Econ. Rev. 4, 5-17. http://dx.doi.org/10.1108/17561371211196748.

Jin, S.Q., Ma, H.Y., Huang, J.K., Hu, R.F., Rozelle, S., 2010. Productivity, efficiency and technical change: measuring the performance of China's transforming agriculture. J. Prod. Analysis 33, 191-207. http://dx.doi.org/10.1007/s11123-0090145-7.

Lei, H., 2003. Modern Agricultural Economics. China Agriculture Press, Beijing (in Chinese)

Li, C.X., Zhang, Y.L., 2012. Analysis on stability factors of grain price in China J. Northeast Agric. Univ. 19, 92-96. http://dx.doi.org/10.1016/s1006-8104(13) 60029-x.

Li, J., Karen, C.S., Bai, J.F., 2015a. Urban economic development, changes in food consumption patterns and land requirements for food production in China. China Agric. Econ. Rev. 7, 240-261. http://dx.doi.org/10.1108/Caer-11-2013 0150

Li, Y.H., Chen, C., Wang, Y.F., Liu, Y.S., 2014. Urban-rural transformation and farmland conversion in China: the application of the environmental Kuznets Curve. J. Rural Stud. 36, 311-317. http://dx.doi.org/10.1016/j.jrurstud.2014.10.005.

Li, Y.R., Long, H.L., Liu, Y.S., 2015b. Spatio-temporal pattern of China's rural development: a rurality index perspective. J. Rural Stud. 38, 12-26. http://dx.doi.org/ 10.1016/jirurstud.2015.01.004.

Lin, J.Y., 1992. Rural reforms and agricultural growth in China. Am. Econ. Rev. 82, $34-51$
Lin, Y., 1994. Institution, Technology and Agricultural Development in China. Shanghai triple Bookstore, Shanghai (in Chinese).

Liu, Y.S., Lu, S.S., Chen, Y.F., 2013. Spatio-temporal change of urban-rural equalized development patterns in China and its driving factors. J. Rural Stud. 32, 320-330. http://dx.doi.org/10.1016/j.jrurstud.2013.08.004.

Long, H., Li, Y., Liu, Y., Woods, M., Zou, J., 2012. Accelerated restructuring in rural China fueled by 'increasing vs. decreasing balance' land-use policy for dealing with hollowed villages. Land Use Policy 29, 11-22. http://dx.doi.org/10.1016/ j.landusepol.2011.04.003.

Long, H., Tu, S., Ge, D., Li, T., Liu, Y., 2016. The allocation and management of critical resources in rural China under restructuring: problems and prospects. J. Rural Stud. 47, 1-21. http://dx.doi.org/10.1016/j.jrurstud.2016.03.011.

Long, H., Zou, J., Pykettd, J., Li, Y., 2011a. Analysis of rural transformation development in China since the turn of the new millennium. Appl. Geogr. 31, 1094-1105. http://dx.doi.org/10.1016/j.apgeog.2011.02.006.

Long, H.L., Woods, M., 2011b. Rural restructuring under globalization in eastern coastal China: what can be learned from Wales? J. Rural Community Dev. 6, 70-94.

Long, H.L., 2014a. Land consolidation: an indispensable way of spatial restructuring in rural China. J. Geogr. Sci. 24, 211-225. http://dx.doi.org/10.1007/s11442-0141083-5.

Long, H.L., 2014b. Land use policy in China: Introduction. Land Use Policy 40, 1-5. http://dx.doi.org/10.1016/j.landusepol.2014.03.006.

McMillan, J., Whalley, J., Zhu, L.J., 1989. The impact of China's economic reforms on agricultural productivity growth. J. Political Econ. 97, 781-807, 10.2307/ 1832191.

Ministry of Agriculture of the People's Republic of China (MAC), 2000. China Agriculture Yearbook 2000. China Agriculture Press, Beijing.

Ministry of Agriculture of the People's Republic of China (MAC), 2001. China Agriculture Yearbook 2001. China Agriculture Press, Beijing.

Ministry of Agriculture of the People's Republic of China (MAC), 2002. China Agriculture Yearbook 2002. China Agriculture Press, Beijing.

Ministry of Agriculture of the People's Republic of China (MAC), 2003. China Agriculture Yearbook 2003. China Agriculture Press, Beijing.

Ministry of Agriculture of the People's Republic of China (MAC), 2004. China Agriculture Yearbook 2004. China Agriculture Press, Beijing.

Ministry of Agriculture of the People's Republic of China (MAC), 2005. China Agriculture Yearbook 2005. China Agriculture Press, Beijing.

Ministry of Agriculture of the People's Republic of China (MAC), 2006. China Agriculture Yearbook 2006. China Agriculture Press, Beijing.

Ministry of Agriculture of the People's Republic of China (MAC), 2007. China Agriculture Yearbook 2007. China Agriculture Press, Beijing.

Ministry of Agriculture of the People's Republic of China (MAC), 2008. China Agriculture Yearbook 2008. China Agriculture Press, Beijing.

Ministry of Agriculture of the People's Republic of China (MAC), 2009. China Agriculture Yearbook 2009. China Agriculture Press, Beijing.

National Bureau of Statistics of China (NBSC), 2000a. China Rural Statistical Yearbook 2000. China Statistics Press, Beijing.

National Bureau of Statistics of China (NBSC), 2000b. China Statistical Yearbook 2000. China Statistics Press, Beijing.

National Bureau of Statistics of China (NBSC), 2001a. China Rural Statistical Yearbook 2001. China Statistics Press, Beijing.

National Bureau of Statistics of China (NBSC), 2001b. China Statistical Yearbook 2001. China Statistics Press, Beijing.

National Bureau of Statistics of China (NBSC), 2002a. China Rural Statistical Yearbook 2002. China Statistics Press, Beijing.

National Bureau of Statistics of China (NBSC), 2002b. China Statistical Yearbook 2002. China Statistics Press, Beijing.

National Bureau of Statistics of China (NBSC), 2003a. China Rural Statistical Yearbook 2003. China Statistics Press, Beijing.

National Bureau of Statistics of China (NBSC), 2003b. China Statistical Yearbook 2003. China Statistics Press, Beijing.

National Bureau of Statistics of China (NBSC), 2004a. China Rural Statistical Yearbook 2004. China Statistics Press, Beijing.

National Bureau of Statistics of China (NBSC), 2004b. China Statistical Yearbook 2004. China Statistics Press, Beijing.

National Bureau of Statistics of China (NBSC), 2005a. China Rural Statistical Yearbook 2005. China Statistics Press, Beijing.

National Bureau of Statistics of China (NBSC), 2005b. China Statistical Yearbook 2005. China Statistics Press, Beijing.

National Bureau of Statistics of China (NBSC), 2006a. China Rural Statistical Yearbook 2006. China Statistics Press, Beijing.

National Bureau of Statistics of China (NBSC), 2006b. China Statistical Yearbook 2006. China Statistics Press, Beijing.

National Bureau of Statistics of China (NBSC), 2007a. China Rural Statistical Yearbook 2007. China Statistics Press, Beijing.

National Bureau of Statistics of China (NBSC), 2007b. China Statistical Yearbook 2007. China Statistics Press, Beijing.

National Bureau of Statistics of China (NBSC), 2008a. China Rural Statistical Yearbook 2008. China Statistics Press, Beijing.

National Bureau of Statistics of China (NBSC), 2008b. China Statistical Yearbook 2008. China Statistics Press, Beijing.

National Bureau of Statistics of China (NBSC), 2009a. China Rural Statistical Yearbook 2009. China Statistics Press, Beijing.

National Bureau of Statistics of China (NBSC), 2009b. China Statistical Yearbook 
576

W. Song et al. / Journal of Rural Studies 47 (2016) 563-576

2009. China Statistics Press, Beijing.

National Bureau of Statistics of China (NBSC), 2010. China Compendium of Statistics 1949-2008. China Statistics Press, Beijing.

Nin-Pratt, A., Yu, B.X., Fan, S.G., 2010. Comparisons of agricultural productivity growth in China and India. J. Prod. Analysis 33, 209-223. http://dx.doi.org/ 10.1007/s11123-009-0156-4.

Odeck, J., 2009. Statistical precision of DEA and Malmquist indices: a bootstrap application to Norwegian grain producers. Omega-International J. Manas. Sci. 37, 1007-1017. http://dx.doi.org/10.1016/j.omega.2008.11.003.

ken, J., Yu, Y., Wang, R., 2009. Preliminary analysis of the environmental impact of Chinese agricultural policy. Chin. Agric. Sci. Bull. 25, 223-229 (in Chinese).

Shepherd, R.W., 1970. Theory of Cost and Production Functions. Princeton Universty Press, Princeton.

Simar, L., Wilson, P.W., 1998. Sensitivity analysis of efficiency scores: how to bootstrap in nonparametric frontier models. Manas. Sci. 44, 49-61. http:/ dx.doi.org/10.1287/Mnsc.44.1.49.

Simar, L., Wilson, P.W., 1999. Estimating and bootstrapping Malmquist indices. Eur. J. Operational Res. 115, 459-471. http://dx.doi.org/10.1016/S0377-2217(97) 00450-5.

Simar, L., Wilson, P.W., 2007. Estimation and inference in two-stage, semi-parametric models of production processes. J. Econ. 136, 31-64. http://dx.doi.org/ 10.1016/j.jeconom.2005.07.009.

Simar, L., 1992. Estimating efficiencies from frontier models with panel data: a comparison of parametric, non-parametric and semi-parametric methods with bootstrapping. J. Prod. Analysis 3, 171-203.

Song, W., Lu, M.L., 2014. Assessment of decoupling between rural settlement area and rural population in China. Land Use Policy 39, 331-341. http://www. sciencedirect.com/science/article/pii/S0264837714000222.

Song, W., Lu, M.L., 2016. Farmland conversion degrease regional and national land quality in China. Land Degrade. Lev. http://dx.doi.org/10.1002/ldr.2518.

Song, W., Pijanowski, B.C., 2014. The effects of China's cultivated land balance program on potential land productivity at a national scale. Apple. Geogr. 46, 158-170. http://dx.doi.org/10.1016/j.apgeog.2013.11.009.

Song, W., Chen, B.M., Chen, X.W., 2009. Evaluation for use efficiency of agricultural resources in grain production: a case study of Changshu, Taine and Ansi in China. Chin. Geogr. Sci. 19, 46-54. http://dx.doi.org/10.1007/s11769-009-00468.

The State Council Information Office of the People's Republic of China (SCIC), 1996. The Grain Issue in China (2006) June 26th. Available at: http://www.fmprc.gov. cn/ce/cgvienna/eng/xnyfgk/t127398.htm (accessed 25.04.16.).

Mimer, C.P., 1971. Using a probabilistic frontier production function to measure technical efficiency. J. Political Econ. 79, 776-794.

Tortosa-Ausina, E., Grifell-Tatje, E., Armero, C., Conesa, D., 2008. Sensitivity analysis of efficiency and Malmquist productivity indices: an application to Spanish savings banks. Eur. J. Operational Res. 184, 1062-1084. http://dx.doi.org/ 10.1016/j.ejor.2006.11.035.

van der Ploeg, J.D., Ye, J.Z., Pan, L., 2014. Peasants, time and the land: the social organization of farming in China. J. Rural Stud. 36, 172-181. http://dx.doi.org/ 10.1016/j.jrurstud.2014.07.002.

Wen, G.J., 1993. Total factor productivity change in China's farming sector: 1952-1989. Econ. Lev. Cult. Change 42, 1-41.

Wu, P.L., Tan, M.H., 2007. Cultivated Land Loss Arising from Rapid Urbanization in China (1996-2005). China Meteorological Press, Beijing.

Chang, Y., Bartels, R., 1998. The effect of sample size on the mean efficiency in DEA with an application to electricity distribution in Australia, Sweden and New Zealand. J. Prod. Analysis 9, 187-204. http://dx.doi.org/10.1023/A: 1018395303580.

Chang, Y., Li, X.B., Song, W., 2014. Determinants of cropland abandonment at the parcel, household and village levels in mountain areas of China: a multilevel analysis. Land Use Policy 41, 186-192. http://dx.doi.org/10.1016/ j.landusepol.2014.05.011. 